\title{
A kognitív térkép és a névhasználat
}

1. Bevezetés. A 20. század második felében a pszichológiából kiindulva számos tudományon, tudományterületen belül végbement az ún. kognitív fordulat (kognitív forradalom), amelynek lényege, hogy a kutatók az emberi tudás mentális hátterét, müködését igyekeznek feltárni. Ez, illetve a kognitív irányultságú kutatásokat egybefogó kognitív tudományok eredendő interdiszciplinaritása teremtette meg a lehetőségét annak, hogy az emberi megismerő rendszer egyik központi eleme, a téri kogníció müködése a szükebb és a tágabb környezetben minél sokoldalúbban, minél komplexebb módon feltárható legyen.

A pszichológusok már a 20. század elején felfigyeltek arra, hogy a rágcsálók meglehetősen gyorsan képesek megoldani útvesztős feladatokat, illetve hogy intelligensen reagálnak a környezet megváltozására (LASHLEY-BALL 1929). EDWARD C. TOLMAN 1940-es években végzett patkánykísérletei után aztán általánosan elfogadottá vált az a feltételezés, hogy az emberi elme - a patkányokéhoz hasonlóan - reprezentációkat készít a téri környezetről. E többféle modalitásból származó információkat magába foglaló reprezentációk szorosabb-lazább összeszerveződéséből épül ki a tájékozódást is segítő dinamikus és szubjektív kognitív térkép vagy kollázs (vö. TOLMAN 1948, TVERSKY 1993, vö. még a kognitív atlasszal: KUIPERS 1982). A helyek reprezentációjához kontextuális információk is kapcsolódnak, többek között arról, hogy mi található ott (milyen étel, víz, eszközök stb.), s a helyek közötti kapcsolatok (távolságok, bennfoglalási viszonyok stb.) is leképeződnek.

A belső térkép ugyanakkor - elnevezésével ellentétben - nem a külső valóság objektív és koherens képe. Ez egyrészt az emberi percepció sajátosságaival magyarázható (ezért van az, hogy az irányokat és távolságokat gyakran a valóságostól eltérően reprezentáljuk), másrészt hatással vannak rá a korábbi egyéni tapasztalatok, illetve az is, hogy a téri információhálózat nem független a helyekhez kapcsolódó érzelmektől, értékítéletektől, melyek egy része a térről való kollektív tudásból származik. Ezek - mint majd látni fogjuk - torzíthatják a téri reprezentációkat. ${ }^{1}$ A pontatlanságok mellett jellemző az is, hogy bizonyos helyek hiányoznak a kognitív térképröl. A tér mentális modellje ugyanakkor nem csupán

* A tanulmány a Magyar Tudományos Akadémia Bolyai János Kutatási Ösztöndíjának és az Emberi Erőforrások Minisztériuma ÚNKP-2018-4 kódszámú Új Nemzeti Kiválóság Programjának támogatásával készült, az MTA-DE Magyar Nyelv- és Névtörténeti Kutatócsoport programja keretében.

${ }^{1}$ A kognitív térkép nemcsak a téri környezet egyes elemeihez kapcsolódó tudást tartalmazza, hanem a társadalmi tér szabályait is: például hogy az egyén hol mit tehet, a nemekre vagy egyes helyekre milyen viselkedési elvárások vonatkoznak stb. (vö. BRÓZIK-KESZEI-DúLL 2019: 22-23). Ezzel a megközelítésmóddal rokon LÁszLÓ ERVIN és munkatársai kognitívtérkép-felfogása (LÁszLÓ et al. eds. 1995²: xii, 4-5). Ez abból indul ki, hogy a társadalmi rendszerek, az emberi közösségek szintjén a térképezésnek új típusa jelent meg: az ember ugyanis olyan környezetben él, amelyben más emberek tevékenykednek, s ezért a humán kognitív térképeknek a helyek mellett az élőlényeket, azok viselkedését, sőt nyelvi absztrakciókat is reprezentálnia kell. 
a közvetlen tapasztalatszerzés révén szerzett vizuális (és más érzékszervi) ismereteket foglalja magában és müködteti, hanem távoli vidékekről, más földrészekről, különböző forrásokból származó tudást is felölel. Vagyis a kognitív térkép egészen különböző térdimenziókban, térnagyságokban, különböző térbeli szinteken segíthet eligazodni.

A pszichológusok mellett, akik kezdetben elsősorban a szükebb környezetben való tájékozódás mentális mechanizmusaira voltak kíváncsiak, neurológusok, pszicholingvisták, nyelvészek, antropológusok, földrajztudósok és kartográfusok egyaránt bekapcsolódtak ezekbe a kutatásokba. Igy formálódott többek között az interdiszciplináris térinformatika, illetve az etnofiziográfia ${ }^{2}$ nevü tudományterület (vö. MARK et al. 1999). E tudományterületek képviselöi gyakran hangsúlyozzák a helynevek szerepét is a téri kognícióban. Ez részben nyilvánvalóan abból adódik, hogy a helynevek nagyban segítik a teret alkotó helyek felidézését, a róluk való kommunikációt. Más oldalról a helynevek tudásszervező szerepével is számolhatunk: e névformák alkalmasak arra, hogy segítségükkel a saját tapasztalatból, másokkal való beszélgetésekből, iskolai tanulmányokból, olvasmány- és filmélményekből vagy épp a médiából stb. származó különböző tartalmú ismeretekhez a tér egy-egy eleme könnyebben hozzárendelödjön. A hellyel kapcsolatos ismeretek egy része továbbá magában a névben is megjelenik, így korábbi idők viszonyaira következtethetünk általuk. ${ }^{3}$ Ennek felismerése ellenére azonban a fenti tudományterületek - érdeklődésükből adódóan - nem végeztek módszeres vizsgálatot a helynevekre vonatkozólag.

A kognitív szemlélet egyre határozottabban érvényesül mindamellett a névtudományon belül is (a nemzetközi szakirodalomban 1. pl. ERNST 2005, SJÖBLOM 2006, a hazai kutatásokban pl. HochBAUER 2008, RESZEGI 2009, SLíz 2012, HoFFMANN 2012), s az utóbbi évtizedben egyre nagyobb hangsúlyt kap a helynévkutatásban a kognitív térkép fogalma is. Ennek alapját az a felismerés adja, hogy a már leképezett téri ismeretek, téri tapasztalatok hatással vannak a térszemléletre, s e kettő szoros kapcsolatban van a helynevekkel is. Egyrészt mivel a nevek is részét képezik a mentális térképnek, az egyes helyekhez kapcsolódó ismeretelemek formájában; másrészt mert e viszonyból adódóan feltehető, hogy a térszemlélet, illetve a mentális térkép hatással van a névadásra és a névhasználatra; s más oldalról esetlegesen a helynevek is formálhatják a térszemléletet (vö. RESZEGI 2012). A kétirányú kapcsolat egy kultúrafüggő aspektusával, a helyneveknek a téri orientációban játszott szerepével korábban részletesen foglalkoztam (vö. RESZEGI 2018). E vizsgálat során kitünt, hogy a természeti népeknél sokkal eröteljesebb hatásokkal számolhatunk a kapcsolat mindkét irányában. Ezzel szemben a modern társadalmakban a helyneveket a legtöbben csupán a helyeket megjelölő címkeként használják, s kevésbé foglalkoztatja öket a nevekben a helyről kifejezett szemantikai tartalom - bár természetesen e körben is találhatunk olyan névhasználókat, akik e téren „tudatosabbak”, és sokkal inkább építenek ezekre az ismeretekre is.

\footnotetext{
${ }^{2}$ A tudományterület a helyet jelölő szavakra, a földrajzi köznevekre, ezek nevekben való megjelenésére, illetve e nyelvi elemeknek a földrajzi objektumok, helyek kategorizálásában játszott szerepére, valamint az emberek és a táj érzelmi és spirituális kapcsolatára fókuszál (MARK-TURK-STEA 2011).

${ }^{3}$ Még inkább hangsúlyozzák a kutatók a helynevek jelentőségét a természeti népeknél. E népcsoportok alig hagyják látható jelét jelenlétüknek a földrajzi környezetükben. Inkább intellektuálisan formálják a tájat, $\mathrm{s}$ a helynevek azok a közvetítők, amelyek révén a földdel való interakció, a korábbi tapasztalatok megoszthatók, a helynevek segítenek megérteni és emberi hellyé formálni a tájat (vö. COLLIGNON 2006: 200).
} 
A kognitív térkép és a hozzá kapcsolódó névanyag és névismeret leírására a (hazai) névkutatáson belül jobbára a várostervezö KEVIN LYNCH (1960) modelljét alkalmazzák a kutatók. E szerint a kognitív térkép utak, csomópontok, tájékozódási pontok, terek és határvonalak mentén szervezödik. LYNCH kizárólag városi környezetben vizsgálódott, s noha modellje az újabb szocioonomasztikai vizsgálatok szerint kisebb méretü településekre is jól alkalmazható (vö. GYÖRFFY 2015a, 2015b, 2017; SZILÁGYI-VARGA 2017a, 2017b), s a névanyag, illetve a névismeret kutatása során is jó alapul szolgál, a földrajzi térben való kiterjesztett, a természetes földrajzi objektumokat is figyelembe vevő vizsgálatok során kevésbé jól használható. Ehhez talán jobban illeszthető SIEGEL és WHITE (1975) pszichológiai modellje, amely a kognitív térképnek lényegében három összetevőjével, három szintjével számol: a legelemibb szintủ tájékozódási pontokkal (landmarks), az ezek mentén kiépülő útvonalakkal (roads), valamint a nagyobb léptékü áttekintéssel a térről (survey). ${ }^{4}$

Írásomban e modellekből kiindulva, de némileg eltérő keretben egyfajta általános öszszegző képet kívánok adni a kognitív térkép, a térszemlélet, illetve ehhez kapcsolódóan a kognitív térképhez kötődő névanyag és a térről való beszéd összefüggéseiről, univerzális és kultúrafüggő sajátosságairól. Ehhez összegzem és a névkutatás szempontjából értelmezem mindazokat a hazai és nemzetközi - földrajzi, társadalomföldrajzi, antropológiai, pszichológiai, illetve szocioonomasztikai és kognitív nyelvészeti - kutatási eredményeket, amelyek a kérdéskörhöz kapcsolódnak. Az antropológiai jellegü vizsgálatoknak köszönhetően egyre színesebb kép rajzolódik ki arról, hogy milyen egyéb konstellációkat vehet fel a kognitív térkép azon túl, amit a nyugati típusú társadalmakban tapasztalhatunk. ${ }^{5}$ Az eredmények összegzésével pedig egyúttal az is kitünik, hogy hol vannak még fehér foltok a téri reprezentációk, illetve a térröl való beszéd és a helynévhasználat összefüggései kapcsán. Az áttekintés során alkalmazott leírási keret reményeim szerint a későbbiekben más, a kognitív térkép müködésével kapcsolatos kutatásokban is eredményesen alkalmazható lesz majd.

2. A kognitív térkép elemei. A tér különböző helyekböl és ezek viszonyából épül fel, s ezek reprezentálódnak a kognitív térképen. Ahhoz, hogy a tágabb földrajzi környezet elemeit és a hozzá kapcsolódó névadási-névhasználati szokásokat le tudjuk írni, LYNCH modelljéhez képest mindenképpen általánosabb helykategóriákkal érdemes dolgoznunk. A helyeknek ugyanis méretük, fizikai és funkcionális sajátosságaik alapján különböző típusait, fajtáit különíthetjük el, s többféleképpen kategorizálhatjuk őket. Méretük, térbeli kiterjedésük alapján beszélhetünk például pontszerü vagy nagyobb léptékben foltszerü (két- vagy háromdimenziós) helyekről. Ide tartoznak a városi környezetben a LYNCH által

\footnotetext{
${ }^{4}$ Ezeket SIEGELék a fejlődés különböző fázisainak is tekintették, az újabb pszichológiai vizsgálatok szerint ugyanakkor párhuzamosan is kiépülhetnek (vö. pl. HIRTLE-HUDSON 1991); a tájékozódási pontok nélküli, útvonal-integrációs (path integration) stratégiának nevezett müködést neurológiai vizsgálatok is támogatják (vö. EPSTEIN et al. 2017: 1507). Amikor ez a stratégia a fellépő tévedések miatt már nem müködtethető, a tájékozódási pontokra támaszkodva újra lehet kalkulálni a helyzetünket (landmark-based piloting). A stratégiák preferálásában egyéni különbségek is vannak.

${ }^{5}$ A globalizációnak, a kommunikációs és térinformatikai technológia fejlődésének, terjedésének, valamint az ebből adódó életmódváltásnak a téri mentális modellre, illetve a helynévismeretre, helynévhasználatra gyakorolt hatásához 1. RESZEGI (megj. e.).
} 
említett csomópontok és a mentális terek; illetve általában véve a terek, az egészként, egységként felfogott helyek, a települések és a természeti objektumok nagy része: a kiemelkedések, szántóföldek, erdőségek, tavak stb. Beszélhetünk továbbá vonalszerü helyekröl, ilyenek az utak, folyók. Ezek nyilvánvalóan nem kizárólagos kategóriák, és az elkülönítésük sem könnyü, hiszen sok esetben az alkalmazott léptéktől függ, hogy egy helyet minek tekintünk. Egy másik szempontot alkalmazva, a kognitív térkép elsődleges funkciója, a térbeli tájékozódás szempontjából beszélhetünk az orientációt segítő tájékozódási pontokról vagy landmarkokról, azaz a téri környezetből mint háttérből kiemelkedő elemekröl, szemben a téri környezet más, az orientáció szempontjából kevésbé jelentős elemeivel. Ezek ugyanakkor megint csak nem állandó és nem mindenki számára azonosan kiépülö kategóriák. A helyek a funkcionalitás egy másik aspektusa szempontjából is jellemezhetők: elkülöníthető az ember alkotta (vagy mesterséges) helyek és a természeti helyek két nagy csoportja (ezek aránya, szerepe az egyének kognitív térképén nyilván jelentős társadalmikulturális különbségeket mutathat). A helyek hasznosítása, az emberek életében betöltött szerepe alapján további kategóriákat lehet elkülöníteni, noha a kategóriahatárok itt sem mindig egyértelmüek. Ezek a sajátosságok (és továbbiak is), vagyis a helyekről való tudásunk elemei komplex módon reprezentálódhatnak a kognitív térképen.

A helyek nyelvi megjelölései kapcsán több kérdés is felmerül: a) milyen helyek, helyfajták kapnak tipikusan nevet; b) mely helyek, helyfajták neve ismert szélesebb körben (a névismeret és a helyfajta összefüggései); c) milyen névadási szokások kapcsolódnak a különböző helyekhez; d) mikor, milyen körülmények között használnak a beszélök neveket, s mikor utalnak a helyre inkább köznévi formákkal.

A kognitív térkép a különböző típusú helyek mellett ezek egymáshoz való viszonyáról, illetve a térben mozgó ember hozzájuk való viszonyáról is tartalmaz információkat. A téri reprezentációk hálózatának jellemzésekor ezért a helyek - és megjelölésük - szempontjából tekintettel kell lennünk a határvonalakra, ki kell térnünk továbbá a helyek egymáshoz képest való elhelyezkedésére, azaz az irányokra, valamint a távolságokra; s emellett a helyek rész-egész viszonya, térbeli érintkezése stb. szintén reprezentálódik az egyének kognitív térképén. Nyelvi oldalról pedig vizsgálni kell, hogy ez a viszonyrendszer miként jelenik meg a térről való beszédben és a helynevekben, s azt is, hogy az ennek kapcsán egyes területeken megfigyelhető névadási-névhasználati szokások mennyire tekinthetők univerzálisnak, vagy mennyire csak az adott közösségre jellemzők.

\section{Helyek és megnevezéseik}

3.1. Tájékozódási pontok. A kognitív térkép szervezésében a kognitív pszichológiai vizsgálatok szerint kitüntetett szerepük van a tájékozódási pontoknak: lényegében ezek köré épül ki a térkép, a téri reprezentációk komplexe. SIEGEL és WHITE (1975: 23) pszichológiai meghatározása szerint a tájékozódási pont (landmark) az észlelési mintázatok olyan egyedi elrendeződése, amely azonosít egy földrajzi elhelyezkedést; olyan stratégiai fókuszpontok, melyhez képest értelmeződik a mozgásunk a térben. E funkcionálisan elkülönülö helytípus kitüntetett szerepét jelzi, hogy az emberek téri beszámolói, hely- és útvonalleírásai is általában a tájékozódási pontokra utalással kezdődnek. DAVID M. MARKék némileg más közelítésmódot alkalmaznak: a környezet bármely sajátos (kulturális) referenciapontjaként határozzák meg a tájékozódási pontot (MARK-TURK-BURENHULTSTEA 2011). 
A tájékozódási pontok jórészt a környezettől elütő, feltűnő jellegüknél fogva irányítják az orientációt, s egészen különböző helyek és objektumok, mesterségesek és természetesek is lehetnek: hegyek, folyók, házak, fák, települések stb. Városi környezetben e funkciót betölthetik távoli, de jól látható természetes vagy mesterséges objektumok, jellegzetes épületek, feliratok stb., illetve az egyének életében fontos szerepet játszó helyek (pl. egyetemisták esetében egyetemi épületek). A térben való mozgás (gyalog vagy járművel) is befolyásolja azt, hogy mely, illetve milyen típusú objektumok müködnek tájékozódási pontként. A referenciapontként szolgáló helyek tehát a közvetlenül megtapasztalható tér szintjén jelennek meg, s nem lehet olyan általános közös külső sajátosságukat megállapítani, ami alapján ezt a szerepüket betöltik. Ez jórészt a környezetükhöz képest, esetenként kulturális ismeretek révén érvényesül (de lehet sajátos forma, szociokulturális jelentőség, szimbolikus funkció stb. is a háttérben). A tájékozódási pontok jellege azonban nyilvánvalóan más a különböző életmódú emberek kognitív térképén, s persze egyéni különbségek is mutatkozhatnak. A természeti népek kognitív térképén - a téri tapasztalatokból adódóan - a természetes képződmények, míg a modern társadalmakban inkább a mesterséges objektumok mint orientációs pontok túlsúlya jellemző. ${ }^{6}$

A tájékozódási pontoknak az emberi közösségek szempontjából két nagyobb csoportjuk van. Egy részük az ott élők többsége számára ismert, hiszen ezek a közös térhasználat helyszínei, így számukra a helyek hierarchiájában magasan állnak. Emellett persze egyéni tájékozódási pontok is szerepelnek az egyének mentális térképén: a saját lakóhely, rokonok lakhelye stb. az adott egyén életében, téri tapasztalatszerzése során szintén referenciapontként szolgálnak. A gyerekek kognitív térképe éppen ezek köré kezd el kiépülni (vö. RESZEGI 2015: 90-94, SZILÁGYI-VARGA 2017a: 179-180), s ez a szerepük a későbbiek során is megmarad.

A kognitív térkép szervezésében való kiemelt fontosságukból adódóan a landmarkokra, orentációs pontokra utalás a térről való beszédben is központi jelentőségü (vö. THIERING 2012: 35-36).7 A környező területről való beszédben is gyakori az e pontokhoz való viszonyítás. HEINRICH ANDREA (2000: 20) a Szatmár megyei, román, magyar, sváb és cigány etnikumú Szaniszló magyar helyneveit, illetve a térről való beszéd sajátosságait vizsgálva igyekezett képet alkotni a magyar nyelvű szaniszlóiak kognitív térképéről, s azt találta, hogy az általa vizsgált személyek egy útvonal leírásakor még a saját névvel jelölt helyek esetében is utalnak a közeli tájékozódási pontra. Kitüntetett helyzetükből adódóan a tájékozódási pontok még olyan esetekben is megőrződhetnek a kognitív térképen, és szerepelhetnek útvonalleírásokban is, amikor a hely a valóságban már eltünt (HEINRICH 2000: 22). ${ }^{8}$

\footnotetext{
${ }^{6}$ További érdekes szempontot vet fel a turizmusföldrajz: egy adott hely mentális reprezentációja másként szerveződik a helyiek és a turisták kognitív térképén, másfajta referenciapontokat, határvonalakat stb. különböztetnek meg (ehhez 1. pl. AUBERT 2014).

${ }^{7}$ A kognitív pszichológia és a kognitív nyelvészet szerint a figura-alap megkülönböztetés alapvető a téri kapcsolatok fogalmi és nyelvi konstruálásában (LANGACKER 2008: 57-60, PINNA 2010).

${ }^{8}$ Például a Békés megyei Doboz község helynévanyagát közzétevő írásból is kitűnik, hogy a belterületen jórészt olyan épületek szolgáltak és szolgálnak tájékozódási pontként, amelyekben bolt üzemelt, míg a külterületen a tanyák épületei és fák (RÉTHY 1989). Ezeknek gyakran olyan esetekben is megmarad a tájékozódásban képviselt szervező szerepük (különösen az idősebbek körében),
} 
Az idevonható, ténylegesen a nyelvhasználatra irányuló kisszámú vizsgálat alapján úgy tünik, az a körülmény, hogy egy hely tájékozódási pontként szolgál, nem feltétlenül eredményezi, hogy tulajdonnévvel jelölik meg (vö. pl. HEINRICH 2000: 19-21). A szükebb téri környezet kapcsán gyakran csak köznévvel utalnak rájuk a beszélök. Ez részben nyilván magyarázható azzal, hogy olyan objektumokról van szó, amelyek nem feltétlenül kell, hogy nevet kapjanak a beszélők névmodellje alapján. A tájékozódási pontok megnevezési és névadási gyakorlata azonban további névtani szempontú vizsgálatokat igényel. Érdemes lenne megnézni azt is, hogy ha van neve a referenciapontnak, az milyen gyakran szolgál alapul a közeli helyek nevének létrehozásához, azaz milyen gyakran jelenik meg más nevekben is, illetve hogy ilyen szempontból találunk-e kulturális különbségeket.

Nagyobb léptékben beszélve a térről, a környezetről, a városias társadalmakban általában a települések, a nagyobb városok szolgálnak viszonyítási pontként, illetve olyan természetes vagy ritkábban mesterséges földrajzi objektumok, amelyek neve széles körben ismert. Bár ilyen jellegü szocioonomasztikai vizsgálatok nem folytak (ezek ugyanis általában egy-egy településre vonatkozóan elemzik a névismereti, névhasználati szokásokat), intuícióink lehetnek arra vonatkozóan, hogy a nagyobb viszonyítási pontokra általában tulajdonnévvel utalnak a beszélők. Már maguk a helyfajták is olyanok, amelyek általában kapnak nevet, illetve a beszélők feltételezik azt, hogy éppen méretüknél vagy általánosan ismert voltuknál fogva a kommunikációs partnerek is ismerik a helyet és nevét, s ezért kommunikációs szempontból hatékony a használatuk.

A természeti társadalmakat vizsgáló antropológusoknak szintén az a benyomásuk, hogy a helyként felfogott tájékozódási pontok minden kultúrában gyakran kapnak nevet (vö. ehhez FOWLER-TURNER 1999: 424), azt azonban nem vizsgálták, hogy ez minden helyfajtára egységesen jellemző-e, vagy akadnak kivételek is. Az azonban nyilvánvaló, hogy a nomád és félnomád életmódot folytató csoportok számára alapvető a földrajzi (biofizikai) környezet beható ismerete. Ez a tudás a saját tapasztalat, megfigyelés mellett a kulturális ismeretátadás eszközeivel hagyományozódott és bizonyos közösségekben hagyományozódik még napjainkban is generációról generációra, s ilyen módon gyerekkortól kezdődően fokozatosan szélesedik a téri ismeretek köre (vö. BARNHARDT 2005, KARI 2003). Nem meglepő, hogy amikor a kutatók arra kíváncsiak, hogy e közösségek tagjai hogyan tájékozódnak, honnan tudják, merre kell menni, olyan válaszokat kapnak, hogy „apám és anyám tudta, mi csak követtük őket” (HENZI 2017: 63). Igen jellemző továbbá, hogy a helyek, tájékozódási pontok köré épülnek ki a természeti, vándorló életmódot folytató népek gyakran ismételt mitikus történetei, úti beszámolói is. S minthogy ezek a történetek a nem írástudó közösségeken belül a kulturális és téri ismeretátadás fontos eszközei, mind a tájékozódási pontok, mind a megnevezéseik fontos szerepet játszanak a közösség tagjainak életében (vö. pl. JETT 2011, COGOS-ROUÉ-ROTURIER 2017, RESZEGI 2018). E közösségek téri gondolkodását a helyek és elnevezéseik szoros, szinte elválaszthatatlan kapcsolata jellemzi, ebből adódóan a tájékozódásban rendre a helynevek szerepét hangsúlyozzák. A mexikói szeri indián népcsoport aktív halászai például azt vallják, hogy a part menti hegyek nevei alapján találják meg a halászóhelyeket (HENZI 2017: 63). A helyeknek és nevüknek a közösség életét szervező szerepéből adódóan nagy valószínüséggel feltehető,

amikor az adott épület a település lakóinak életében betöltött közösségszervező funkcióját elveszítette, vagy akár maga az épület is eltűnt. Ezek megnevezése az idősek körében nem változik, továbbra is referenciapontként használják öket. 
bár természetesen mindenképpen igazolásra szorul, hogy az egyének névismerete sokkal hasonlóbb lehet egymáshoz az ilyen típusú társadalmakban, mint a modern társadalmakban. Az ilyen irányú vizsgálatok azért is fontosak lennének (s nem csupán a nomád, vándorló életmódot folytató népcsoportoknál, hanem a letelepült közösségekben is), mert az így feltárt névismereti, névhasználati jellemzők alapján nagyobb valószínűséggel fogalmazhatnánk meg feltevéseket a korábbi idők névhasználatával kapcsolatban is. E társadalmakban is megfigyelhető ugyanakkor az életmódváltással, a modernizációval párhuzamosan a névismeret visszaszorulása. A már idézett szeri népcsoportban például a korábbi vándorló, vadászó-gyüjtögető életmódot fokozatosan felváltja a falvakba települt életforma, a vadászat helyett pedig kezd a halászat dominálni, s az életmód és élettér változásával összefüggésben a fiataloknak már alig van ismeretük a korábbi táborhelyekröl, a nevüket sem tudják. (Vö. HENZI 2017.)

3.2. Mentális terek. A kognitív térképen a földrajzi környezet percepciósan feldolgozott további elemei is reprezentálódnak: a referenciapontok épp ezekhez képest értelmezhetők. Természetesen attól függően, hogy mennyire jól ismerjük az adott környezetet, e helyek mentális reprezentációjának kidolgozottsága igen különböző.

A modern városias életformájú társadalmakban az emberek jórészt a városhatáron belül élik életüket, nem meglepő tehát, hogy a társadalomföldrajzi és a szocioonomasztikai vizsgálatok egyaránt azt tárták fel, hogy a belterület helyei és elnevezései jórészt viszonylag kidolgozottak a lakók mentális térképén, szemben a külterület, illetve a tágabb földrajzi környezet képével. A helyreprezentációkhoz értékítéletek is tartoznak, s a fontosnak tartott részeket jellemzően nagyobbnak is tartják, míg a kevésbé fontos helyek elmosódnak. Ez általában véve jellemző a helyek reprezentációjára, és a helyként felfogott tájékozódási pontok esetében is érvényesül. Ez a szemléletmód figyelhető meg az USA-ról egy texasi szemszögéből rajzolt térképen, melyen az államok nevének kifigurázása jól szemlélteti az egyes régiókkal szembeni előítéletet (DOWNS-STEA 2006: 600). Az értékítéletek származhatnak személyes tapasztalatból, de gyakran sztereotípiák húzódnak a háttérben (vö. MiCHALKÓ 2008: 100).

Kisebb léptékben szemléltetik ezt a jelenséget SZILÁGYI-VARGA ZSUZSÁnak (2017a) egy romániai aprófaluban, Kisbábonyban végzett vizsgálatai, melynek során a kutató arra volt kíváncsi, hogy miként reprezentálódik az ott lakók számára a falujuk, pontosabban csak a belterület, és hogy ez a névhasználatban hogyan tükrözödik. A települést két, etnikai, felekezeti, területi alapon, valamint kapcsolatrendszerét, nyelvhasználati szokásait, végzettségét és foglalkozását tekintve is elkülönülö koherens, homogén közösség lakja. A magyar és a cigány közösség ugyanakkor eltérően értelmezi a belterületet, a települést, a két csoporton belül viszont nagyfokú hasonlóság figyelhető meg. A magyarok a magyarok lakta városrészt tekintik a falunak, a cigányok lakta rész gyakran meg sem jelenik az általuk rajzolt térképeken, vagy csak elmosódottan, kicsiben. A cigány közösség mentális térképén szintén a saját lakóhely szerepel felnagyítva, ez szervezi a település reprezentációját. A jelenséget CSÉFALVAY ZOLTÁN geoegoizmus-ként írja le (1990: 14), ami megfeleltethető SZILÁGYI N. SÁNDOR etnocentrikusság fogalmának (1997: 27), s a helyekhez kapcsolódóan reprezentált értékítéletekre vezethető vissza.

A beszélők térszemléletében megmutatkozó, az értékítéletből adódó különbségeket a névhasználat is tükrözheti. HEINRICH ANDREA (2000: 9) már idézett vizsgálata szerint az 
idősebb szaniszlóiak a Karoly és a Liget nevet, noha települések nevei, a külterületek neveihez hasonlóan névelővel használják, a két betelepített lakosságú helység ugyanis számukra „nem minősül igazi, prototipikus településnek”. A fiatalabb generáció azonban már nem tesz különbséget: amint a nyelvhasználatuk is mutatja, névelő nélkül használják a két nevet, hasonlóan a többi szomszédos település nevéhez.

A városon belül egy sajátos térszerveződés is megjelenik: a szociálisan, kisebb-nagyobb közösségekhez kapcsolódóan szerveződő térrészeket LYNCH nyomán mentális terek-nek nevezik. A kognitív térkép sajátosan szubjektív volta legszembetűnőbben talán ezek esetében nyilvánul meg: a mentális terek egy részét, s ehhez kötődően a tereket jelölő neveket is gyakran eltérő módon értelmezik a lakók (vö. LETENYEI 1999). A mentális tér fogalma ugyanakkor a kisebb települések kapcsán is értelmezhető. Kisbábony például hivatalosan egyetlen utca, de több térre és altérre osztják a lakók. A településrészek felfogásában a két közösség között szintén különbség, míg a közösségeken belül hasonlóság mutatkozik. SZILÁGYI-VARGA ZSUZSA vizsgálataiból az is kitünik, hogy a mentális reprezentációjuk alapján elkülönülö térrészeknek nem feltétlenül van nevük (2017a, 2017b). Hasonlóan szociálisan szerveződő helyekkel a természeti népeknél is számolhatunk: a pápua új-guineai félnomád eipók településén is elkülönül a központ, a szent/felszentelt „férfiak háza”: minden, a közösség szempontjából fontos helyet e köré alakítottak ki, míg a „nők háza” a periférián helyezkedik el (THIERING-SCHIEFENHÖVEL 2016: 67). Arról azonban, hogy ez a névadást és névhasználatot miként befolyásolja, nincsenek ismereteink.

Az értékítéletek téri reprezentációt befolyásoló szerepe, mint látható, a különböző léptékü ráközelítésekben egyaránt jellemzi a kognitív térkép kiépülését. Noha az idézett példák szinte kivétel nélkül a modern társadalmak térszemléletéhez kapcsolódnak, e szerep valójában a kognitív rendszer egyik általános müködési elvének tekinthető, azaz hasonlóan jelen kell lennie a természeti népek kognitív térképének müködésében is.

Szintén általános jelenség lehet (bár ez még megerősítésre szorul), hogy egy helyet több névvel is jelölhetnek. A magyar, illetve európai gyakorlatban ez jól ismert (sőt azt is igyekeznek feltárni, hogy mely helyeknek van jellemzően több nevük, s mi befolyásolja ezt), ám más társadalmakban már kevésbé. Ez összefügg azzal, hogy a körükben kutatást végző szakemberek nem névkutatók, s a neveknek csak a saját kutatási területük szempontjából lényeges aspektusait írják le. Az ausztráliai bininj gunwok dialektus névhasználói gyakorlatában ugyanakkor annyira jellemző egy adott szálláshely két névvel, egy úgymond hivatalos, valamint egy helyi, közösségen belüli névvariánssal való megjelölése, ${ }^{9}$ hogy ez megragadta a kutató figyelmét (GARDE 2014). Szintén találunk példát alternatív névpárokra az északamerikai navahó indiánok körében: ezek lehetnek világi és szakrális megjelölések, de több szekuláris névváltozattal is jelölhetik ugyanazt a helyet (JETT 1997: 490).

3.3. Földrajzi környezet. A külterületet, illetve általában véve a természeti környezetet is összefüggőnek tartott, egy helyként felfogott térrészek alkotják, s ezek szintén fontos részét képezik/képezhetik a kognitív térképnek (annál is inkább, mivel ilyen természeti helyek a belterületen belül is találhatók). Ennek kapcsán ugyanakkor szem előtt kell tartanunk, hogy míg a mai modern társadalmakban a belterületnek és névanyagának a reprezentációja viszonylag kidolgozott, addig a külterületről és neveiről csak a helyiek kis részének - jórészt a határban dolgozóknak - van ismeretük (vö. GYŐRFFY 2015a: 110).

\footnotetext{
${ }^{9}$ Ezeknek ráadásul használati értékre vonatkozó megnevezésük is van (big és small names).
} 
Ezzel is összefüggésben nem ritka az a névhasználati jelenség, hogy a beszélők kiterjesztik az általuk ismert helyneveket: azaz ha ismernek, és nagyjából lokalizálni tudnak egy adott helynevet a határban, a környező helyek neveit viszont nem, akkor gyakran az ismert névformával utalnak a szomszédos területekre is. Ez magyarázható olyan módon, hogy ők eleve nagyobb terület megjelöléseként tanulták meg az adott nevet, másrészt viszont a használatban megmutatkozó metonimikus kiterjesztésként is értelmezhető. Hasonló metonimikus névhasználatról számol be, különböző példákat is említve STEPHEN C. JETT a navahók névanyagát vizsgálva a Chelly-kanyonban. Például a Tséyaakini 'barlanglakás' név egyszerre jelöl egy sziklalakást a föszurdokban, valamint egy közeli oldalsó szurdokot és egy ösvényt az oldalsó kanyonnál (további példákhoz 1. JETT 1997: 489). Szintén jellemző ez a névhasználati mód az alaszkai athabaskanokra (vö. KARI 1989).

A természeti népek életmódja ugyanakkor szervesen kötődik a biológiai-földrajzi környezethez. Esetükben, még ha vannak is állandó vagy ideiglenes településeik, szálláshelyeik, ezek jellemzően a földrajzi környezet részeként értelmeződnek, nem választódnak el tőle.

A térszemlélet müködése szempontjából lényeges maguknak az egységként felfogott helyeknek a kategorizálása is, azaz a helyfajta megállapítása. A helyfajtáknak a fogalmi kategóriái - a különböző forrásokból származó téri, földrajzi ismereteknek köszönhetően - fokozatosan árnyaltabbá válnak a világ megismerése és az anyanyelv-elsajátítás során. A kutatókat jó ideje foglalkoztatja, hogy vajon ezek a téri fogalmi kategóriák, illetve a földrajzi köznevek állománya mennyire tekinthető univerzálisnak, azaz hogy az összefüggő tér szegmentálása milyen általános és specifikus jegyeket mutat. Az idevágó, számos kultúra és nyelv tanulságait összevető vizsgálatok (vö. BURENHULT-LEVINSON 2008, MARK et al. eds. 2011) mind arra utalnak, hogy ebből a szempontból jelentős különbségek mutatkoznak a különböző kultúrák, nyelvek között. Még az olyan alapvetőnek feltételezett fogalmak, mint a kiemelkedések vagy a vízfolyások megjelölései is jelentős különbségeket mutatnak. Sőt az univerzálisnak gondolt fogalmak egy részéről kiderült, hogy nem minden nyelvben van megfelelöjük: a dél-ázsiai lao és a melanéziai yélî dnye nyelvben például nincs 'völgy' jelentésü szó (vö. ENFIELD 2008, LEVINSON 2008). A helyek kategóriájának megítélése, illetve az, hogy milyen földrajzi köznévvel beszélnek róluk, számos tényezőtől függ. Egyértelműen hatással van rá maga a földrajzi környezet, hiszen a földrajzi viszonyok jelentősen különböznek a föld különböző pontjain. Ezért például a sík területeken a földfelszín egészen kis méretü kiemelkedéseit is 'halom'-ként, 'domb'-ként, sőt esetleg 'hegy'-ként jelölik meg a beszélők, míg a hegyvidéki területeken csak a magasabb kiemelkedéseket nevezik meg ilyen módon (vö. RESZEGI 2008). Ez a szemléletbeli különbség egyetlen nyelven belül is érvényesülhet. A földrajzi környezet jellemzői hatással vannak arra is, hogy a helyjelölő szavak csoportja az adott területen hogyan épül ki; például tavakban gazdag vidéken jellemzően gazdagabb a vízrajzi köznevek köre. Ez azután visszahat a tér észlelésére, ugyanis ha vannak szavak bizonyos különbségek megjelölésére, nyilvánvalóan használják is őket.

Ezzel a fajta kulturális-nyelvi meghatározottsággal magyarázható, hogy még hasonló természetföldrajzi környezetben élő népcsoportok fogalmi készlete is mutathat jelentős különbségeket. A különböző típusok elkülönítésében ugyanis a helyfajta számos tulajdonságára támaszkodhatnak a beszélők: a kiemelkedések esetében például a méret, alak, anyag, hasznosítás egyaránt fontos szempont lehet a különböző kategóriák 
megállapításakor. ${ }^{10}$ Jól szemlélteti ezt az indonéziai nyugat-pantar nyelvet beszélő közösség vízrajzi köznévi készlete. A szélsőséges, vulkáni környezetben élő nép ugyanis a nyugati kultúrkörben megszokottól igen eltérő módon kategorizálja a vizeket. Az életben maradásukhoz nélkülözhetetlen iható vizeket egyetlen szóval jelölik meg, függetlenül attól, hogy ezek források, patakok vagy tavak, lagúnák, illetve friss vagy állott, kevésbé tiszta vizek; ezzel áll szemben a sós tengervizes helyek megjelölése. Ezek mellett azonban további kategóriákként a vulkáni müködés miatt savas vizeknek két típusát is megkülönböztetik: az enyhén savas, s ezért mosásra alkalmas, illetve a nagyon savas, ezért csupán egyfajta orvosi kezelés során alkalmazható vizeket (HOLTON 2011a: 161-164). A szókészlet kulturális meghatározottsága jól szemléltethető továbbá egy sajátos alaszkai példával. Az itt élő atapaszka és eszkimó (inuit és jupik) nyelveket beszélő népcsoportok területe egy igen hosszú szakaszon határos, s a vidéket a két nyelv beszélői másként konceptualizálják; ez figyelhető meg mind a hegyrajzi, mind a vízrajzi fogalmak esetében. A témával foglalkozó kutató, GARY HOLTON (2011b) szerint ennek hátterében részben az állhat, hogy az eszkimó nyelvet beszélők part menti területének földrajzi viszonyai, a terület egészének arculata alapvetően eltér az atapaszka nyelvcsaládba tartozó nyelveket beszélők által birtokolt és ismert, sokkal változatosabb domborzatú vidéktől, s az ezeket a viszonyokat leíró szókészletet alkalmazzák a közös határvidék leírására is.

Az etnofiziográfiai vizsgálatok a földrajzi fogalmak, földrajzi köznévi kategóriák eltérései mellett különbségeket találtak például a testrésznevek metaforikus földrajzi köznévként való használatában is (BURENHULT-LEVINSON 2008: 142-143). A kognitív nyelvészet szerint a megismerő rendszer alapvető jellemzője a testben levés tapasztalata: az emberi test müködése meghatározza az érzékelhető dolgok körét, a világ értelmezésében is fontos szerepet játszik, s igen gyakran szolgál az absztraktabb jelentések értelmezését segítő forrástartományként a metaforák nyelvi megvalósulásaiban. A testrésznevek metaforikus szemléleten alapuló, földrajzi köznévként való használata tehát akár univerzális jelenség is lehetne, ám LEVINSONék szerint ebben is mutatkoznak különbségek (BURENHULT-LEVINSON 2008: 142-143). Ennek alaposabb feltárása mind a kognitív nyelvészet, mind a névkutatás szempontjából igen tanulságos lenne. Mindenképpen sajátos ebből a szempontból a Malájfélszigeten élő, vadászó-gyüjtögető életmódot folytató dzsahai népcsoport térjelölése: náluk is megjelenik ugyan a testrészek metaforikus használata, ám NICLAS BURENHULT (2005: 19-24) szerint nem az álló, hanem az arccal lefelé fekvő testhelyzet szolgál a testrésznevek metaforikus használatának alapjául.

A tér szemlélete, kategorizálása a névadásban is megjelenik. Jól szemlélteti ezt az inuitok térszemlélete: amit ugyanis a területet nem ismerők egybefüggő, végtelen hó- és jégmezőnek látnak, azt az ott szocializálódó inuitok tagoltnak érzékelik, s ebben segítik őket a helynevek is (APORTA é. n., 2009). A helyek kategorizálásának vannak a tér holisztikus szemléletéből adódó sajátos esetei is, amikor különböző típusú, de a környező tájban jellemzően együtt előforduló helyeket egyetlen helyként jelölnek akár közszóként, akár

10 Jól magyarázható ez a kognitív pszichológia és a kognitív nyelvészet megközelítésével: a fogalmi kategóriák tulajdonságjegyei közt vannak fontosak és kevésbé fontosak, s részben a nyelv közvetítésével tanuljuk meg, hogy a fizikai környezet elemeinek mentális feldolgozása, s ennek részeként kategóriába sorolása során mely sajátosságokat kell nagyobb súllyal figyelembe venni, $\mathrm{s}$ melyek kevésbé meghatározók. 
tulajdonnévként. Én magam az erdő- és hegyneveknek, illetve a két helyfajtának az összefonódását vizsgáltam (RESZEGI 2009). A megismerési folyamat eredményeképpen a kiemelkedést és az azt borító erdőséget az egyén nem választja el élesen egymástól, a két objektumot valójában egyazon denotátumként dolgozza fel. Ezt a szemléletet pedig a névhasználat maga is támogatja, vagyis a viszony kölcsönös: nincs elkülönült neve az összetartozó helyeknek, ezért nem is tekintik külön objektumoknak őket. A két helyfajta hasonló összefonódását GYÖRFFY ERZSÉBETnek a névadói kompetenciára irányuló vizsgálata is kimutatta: a résztvevőknek különböző névformák névszerüségét kellett megítélniük, illetve egy tájleírás alapján saját maguknak kellett nevet adniuk különböző helyeknek. Ennek során többen alkottak holisztikus szemléletröl árulkodó neveket (GYÖRFFY 2018: 79-80). Hasonló jelenségről számol be HOCHBAUER MÁRIA (2007: 14) a négyfalusi névanyagot vizsgálva: az árok szóval egyaránt jelölnek völgyet és annak patakját, a kétfajta objektumot a nyelvi világban egyetlen egészként észlelik.

Az etnofiziográfiai vizsgálatokból kitünik, hogy a magyar nyelvü példák mellett más kultúrák névhasználatában is megfigyelhető ez a fajta térszemlélet. A már idézett nyugatpantar nyelv beszélői számára például a térszíni formák kevésbé fontosak, pontosabban ezeket inkább csak a rajtuk kialakított, kulturális szempontból jelentős települések, kertek, totemikus helyszínek hátterének tekintik. Ez gyakran a névadásban is megjelenik: a kétféle hely gyakran viseli ugyanazt a nevet, feltehetően metonimikus névadás eredményeként. Ök sem érzik, hogy az azonos név zavarná a kommunikációt, s nem is igénylik, hogy a kontextusban valamilyen módon egyértelmüvé tegyék, melyik helyről van szó: számukra „a falu a domb, és a domb a falu” (HOLTON 2011 a: 150, 144, fordítás tőlem, R. K.).

A holisztikus szemlélettel ellentétes térfelfogásra is találunk ugyanakkor példát, akár a mai magyar névanyagban is: nem ritka, hogy a vízfolyások egyes szakaszai más-más nevet viselnek. Természetesen a szakasznevek a névadás korának térszemléletét tükrözhetik (még ha ennek hatásával a későbbiekben is számolhatunk). Feltehető, hogy a nevek különböző beszélőközösségekhez köthetők, melyeknek tagjai nem voltak tudatában annak, hogy az adott vízfolyást másutt máshogy nevezik; de akár ennek ismeretében is létrehozhattak egy másik nevet. Hasonlóan homályba vész a nyugat-pantar beszélök szakaszneveinek a létrejötte is. A nevek ugyanakkor napjainkban is használatban vannak, noha az ott lakók tudják, hogy ugyanazon vízfolyás különböző részeiről van szó (HOLTON 2011a: 162-163; magyar vonatkozású, jelenkori és történeti magyar példákhoz 1. HoFFMANN 2010, RESZEGI 2015).

A már említett dzsahai népcsoport térszemléletében és névadásában igen sajátos módon jelenik meg a kétféle látásmód: nyelvükben vannak ugyan szavak a különböző helyfajtákra, de ezek szinte sosem jelennek meg a helynevekben, s a nevek maguk sem tekinthetők a hagyományos értelemben vett neveknek. Nem elkülönülten jelölnek meg ugyanis egy kiemelkedést vagy vízfolyást, hanem több különböző helyfajtát (pl. egy vízfolyás egy szakaszát, illetve a környező partot és a szomszédos területeket) magukba foglaló egységek neveként használatosak. Ilyen jelentésü földrajzi köznév ugyanakkor nincs a dzsahai nyelvben. (BURENHULT 2005.)

A helyek, helyfajták konceptualizálásában megmutatkozó különbségek más módon is megragadhatók: kultúránként változó az is, hogy a különböző fajtájú helyek közül mi kap nevet. Az európai kultúrkörben jellemző, hogy a szántóföldeknek van nevük, s ezt láthattuk a nyugat-pantar közösség esetében is. Ezzel szemben a mexikói celtál nyelvü közösségben a megmủvelt területeknek ritkán van nevük, de a vándorlási útvonalak, gyalogösvények 
mentén sok a névvel jelölt hely, s a szentnek tartott forrásoknak, hegyeknek is van nevük (BROWN 2006: 179). Ez a gyakorlat természetesen - például kulturális hatásra - változhat. A legutóbbi időkig vándorló nomád életmódot folytató dzsahaik nyelvében például a településre nincs szó - feltehetöen összefüggésben az életmódjukkal -, s az újabban létrejött települések nevei is maláj eredetüek (BURENHULT 2005: 27).

Mindez úgy magyarázható, hogy az anyanyelv-elsajátítás, illetve a világ megismerése, a szocializáció során az elsajátított nevek, illetve ezek használata alapján a különböző helyfajtákhoz kötődő névadási-névhasználati szokásokról is lesznek ismereteink: a nevek reprezentációjából válik ki ez a fajta tudás. HOFFMANN ISTVÁN a névrendszertani vizsgálatok kapcsán hívja fel a figyelmet arra, hogy az egyes helyfajták esetében a névadás során különböző normák lépnek működésbe, ami a denotátumok entitásbeli különbségén, ezen belül a rájuk vonatkozó szemléleti kategóriák eltérésén alapul (1993: 33, vö. még HOFFMANNRÁCZ-TÓTH 2018: 113-127). A navahók nevei például túlnyomórészt áttetsző, a hely és a környezet sajátosságait leíró szerkezetek, s csupán a településnevek, szálláshelyek esetében találkozunk más motívumokkal: birtoklásra, esetleg eseményre utalással, elvétve átvétellel (JETT 2011: 329-330). A névmodellek, névadási-névhasználati normák szerepét különösen fontos szem elött tartanunk akkor is, amikor a nevek alapján igyekszünk a térszemléletre következtetni. (Az ilyen jellegü névkompetenciáról a magyar beszélők esetében vö. még GYÖRFFY 2018 már idézett felmérését.)

A helynevek esetében a név és az általa megjelölt objektum kapcsolatában elmozdulást hozhat a jelölt dolog megváltozása: ez ugyanis nyilván változást eredményez az érzékelésben, a hely reprezentációjában. S noha nem feltétlenül jár együtt a név módosulásával, a használatára hatással lehet. Ezt szemlélteti HEINRICH (2000: 10) szaniszlói példája: a településen az erdős területek nevéhez a távoli külső helyviszonyra utaló toldalékokat (-hoz/-hez/-höz, -nál/-nél) kapcsolják: Fenyveshez, Fenyvesnél. A korábban szintén erdös tájegységekre vonatkozó Pétererdö, Csere, Nyires nevekkel azonban napjainkban már szántót, parlagot jelölnek, s ezt a kapcsolódó toldalékok is tükrözik: Pétererdöre, Cserére, Nyíresbe. E névhasználati jelenség kapcsán ugyanakkor további vizsgálatokra van szükség, hogy magyarázni tudjuk, a FELÜLETEN LEVÉS, illetve a TARTÁLYBAN LEVÉS viszonyok miért funkcionálhatnak itt szinonimaként, szemben a távoli külső helyviszonyra való utalással (a helyviszonyt kifejezö esetragok kognitív nyelvészeti megközelítéséhez l. SZILÁGYI N. 1997: 27-29, TOLCSVAI NAGY 2017: 284-288).

A kognitív térképen reprezentált helyekröl, mint láttuk, nem csupán szigorúan vett földrajzi ismereteket tárolunk, hanem a helyre vonatkozó saját emlékeket, történeteket, eseményeket, érzelmeket, illetve az enciklopédikus ismereteket is ehhez kapcsolódva tároljuk és müködtetjük. A természeti népek kapcsán pedig több antropológus is hangsúlyozza a helyekhez kapcsolódó spirituális ismeretek jelentőségét. „Az őslakos ausztrálok, köztük a yindjibarndik számára a spiritualitás és a topográfia elválaszthatatlan." Valamennyi állandó vízlelőhelynek (yinda) van egy szelleme (warlu), amely meghatározza, hogy hogyan kell viselkedni az adott helynél. (MARK-TURK 2003: 45, a szerző fordítása.)

3.4. Utak, utcák, útvonalak. A kognitív térkép fö funkciója, hogy erre támaszkodva, ezt müködtetve mozogni tudjunk a térben, környezetünkben. Ehhez alapvető az utak, útvonalak reprezentációja. Az utak kétdimenziós helyekként, térrészekként, illetve a helyek, jellemzően a tájékozódási pontok mentén kirajzolódó komplexebb, a tájékozódási pontok 
sorrendjét, valamint metrikus információkat is magában foglaló téri reprezentációként, valamint ennek müködéseként, azaz egyfajta procedurális tudásként is értelmezhetök (BUCHNERJANSEN-OSMANN 2008).

Az utak különösen fontosak a belterület kognitív térképének szervezésében napjaink modern társadalmaiban; a legtöbb lakó belső térképén ezek a leginkább domináns elemek. Az utak mentén történik a haladás, a közlekedés - a városkutatók szerint ezek a városkép keretelemei. A szocioonomasztikai vizsgálatok szerint a beszélök által ismert nevek legnagyobb hányadát a városias életmódból adódóan út- és utcanevek teszik ki (GYÖRFFY 2015b, E. NAGY 2015). S minthogy e jórészt a legutóbbi időkben keletkezett nevek jellemzően (a második névrészt leszámítva persze) nem tükrözik a hely sajátosságait, megítélésem szerint - az általánosan ismert átlátszatlan makrotoponimák mellett - igen fontos szerepet játszanak abban, hogy a modern társadalmakban az emberek nem várják el a nevek lexikális arculatáról a hely sajátosságainak tükrözését. ${ }^{11}$

Az utak, útvonalak emellett persze a tágabb földrajzi környezetben is értelmezhetők: a településeket összekötő útvonalak mellett a gyalogösvényekre, túraútvonalakra is gondolhatunk. Míg az előbbieknek általában van - jobbára hivatalos névadással adott - nevük, addig az utóbbiakról viszonylag keveset tudunk. ${ }^{12}$

A városias életmódban szocializálódva, illetve akár a középkori névanyagban fellelhetö útnevek alapján (vö. HOFFMANN-RÁCZ-TÓTH 2018: 455-457) azt feltételezhetnénk, hogy a települések utcák, utak szerinti szerveződése és ezek elnevezése másutt is általános. Ám például a tanzániai névanyag vizsgálatából kitűnik, hogy a települések utcák szerinti felosztása, illetve utcanevek adása csupán a 20. században jelent meg, a német gyarmatosítók tevékenységének eredményeként. Az utcák, utcanevek bevezetése azonban az ott élők térszemléletét nem vagy csak alig változtatta meg (MUGEREZI 2002: 84, RIEGER 2014). Ez ugyanakkor nem jelenti azt, hogy az ő kognitív térképükön ne lennének útvonalak: az ő esetükben ezek nem egy egységként felfogott térrészként, hanem komplexebb téri rendszerelemként értelmezhetők.

Egy életmódjában talán valamivel a nyugati társadalomhoz közelebb álló példa szintén azt mutatja, hogy az utcák szerinti településszervezés nem univerzális. Japánban ettől alapjaiban eltérő térrendszer dominált egészen a 20. század végéig: a keresztezési pontoknak szenteltek kitüntetett figyelmet. Csak az útkereszteződéseknek volt nevük, s egy kereszteződésnek mind a négy sarkát más-más névvel jelölték, magának az útnak viszont nem volt akkora jelentősége. Ezzel összefüggésben a házakat sem téri rendjük szerint, hanem időben viszonyították egymáshoz: felépülésük sorrendjében számozták őket (HALL 1995²:

${ }^{11}$ Az efféle utcanevek azért terjedhettek el ilyen nagy számban - felváltva a középkorban jellemző sajátosságjelölő típust -, mert megváltoztak a szociokulturális körülmények. Az újkortól kezdve például adminisztrációs és egyéb okokból minden utcának nevet kellett adni, ugyanakkor szintén kívánalom volt, hogy ne legyen több azonos utcanév egy településen belül. Az utcák nagy száma miatt nem mindegyiknek tudtak rá jellemző nevet adni névazonosság nélkül, ezért fokozatosan terjedtek a ma ismert címkeszerü nevek, ez pedig a névismeret átrendeződésével az emberek névmodelljét is átalakította.

${ }^{12}$ Az utak megnevezése kapcsán utalhatunk egy mind névhasználói körét, mind nyelvi felépítését tekintve sajátos, néhány évtizede megjelenő névcsoportra, a sziklamászó utak neveire (1. pl. BAUKO 2015: 127-130), ám az út- és utcanevekhez képest ezek - legalábbis a magyar helynévanyagban, még a névanyagot ismerők helynévmodellje szempontjából is - periférikusak. 
119, 162-163). (Ez a szemléletmód az amerikai megszállást követően a nagyvárosokból kiindulva fokozatosan átalakult.)

4. A helyek viszonyai. Egy adott helyet mindig más hely(ek)hez való viszonyában szemlélünk. Ezeket a viszonyokat szintén leképezzük a helyekkel összefüggésben a kognitív térképeinken. Itt utalni lehet a helyek közötti határokra, az irányokra, távolsági viszonyokra, a helyek rész-egész és egyéb viszonyaira.

4.1. Határok. A határok lényegi tulajdonsága - függetlenül attól, hogy fizikai mivoltukban megjelenő vagy immateriális határokról van-e szó -, hogy egyszerre képesek a vég és a kezdet megtestesítésére, illetve a köztük lévő átjárhatóság biztosítására (vö. MICHALKÓ 2008: 146). Ebből kiindulva, noha LYNCHnél helyfajtaként jelentek meg, megítélésem szerint nem kevésbé indokolt a viszonyok között tárgyalni ezeket, hiszen két vagy több hely viszonyában értelmezhetők.

A tér reprezentációjára irányuló kutatások jórészt a települések, illetve a mentális terek határát, az arról való tudást célozzák. Egy település kapcsán alapvetően két határvonalat vizsgálnak: a bel- és külterület határát, illetve a települést más településektől elválasztó határvonalat. Az eredmények egyértelmüen azt mutatják, hogy az embereknek nincs pontos képük ezekről (vö. GYÖRFFY 2015a, HEINRICH 2000: 26). SZILÁGYI-VARGA ZSUZSA a saját téri tapasztalat fontosságára hívja fel a figyelmet a határok reprezentálásával kapcsolatban: „hogy kinek meddig tart a falu, elsősorban annak függvénye, hogy ki milyen napi/heti, esetleg havi térpályákat tudhat magáénak" (2017b: 188).

A belterületi mentális terek határai - annak ellenére, hogy ezeket túlnyomórészt a térképek nem jelölik - jobbára nagyobb hasonlóságot mutatnak egy település lakóinak mentális térképén (vö. LETENYEI 1999).

A határok persze általánosabban is vizsgálhatók a helyek vonatkozásában. Amint viszont az a kognitív szemléletü antropológiai vizsgálatokból kitünik, a természeti objektumoknak jobbára nincs pontos határuk. A helyek (a helynevekkel jelölt területek is) foltokként követik egymást a beszélök mentális térképén (HEINRICH 2000: 28-29), tehát jórészt elmosódó, bizonytalan határokkal, időnként átfedő helyreprezentációkkal számolhatunk.

A határok emellett nagyobb léptékben is jelen vannak a mentális térképeken. A különböző alapon szerveződő tájegységek határai jobbára szintén nem húzhatók meg élesen. Az országhatárok határozottabbak, különösen a határ mentén élök tudatában. Ennek kapcsán hangsúlyozza HAJDÚ ZOLTÁN (2015: 45-48), hogy minden területi változás (általánosan véve: politikai változás, államhatár módosulása stb.) új térszemléletet és gyakorta új földrajzinévanyagot is jelent.

A határoknak jórészt nincs nevük, legalábbis az eddigi vizsgálatok ezt mutatják. HEINRICH ANDREA ugyanakkor rávilágított arra, hogy a határoknak bizonytalan voltuk ellenére is fontos szerepük van a térről való beszéd szervezésében, ez irányítja ugyanis a KINT-BENT dimenzió müködését az általa vizsgált közösségben. Ha egy adott úton közlekedik valaki azzal a céllal, hogy átlépje a határt, azaz átmenjen egy másik településre, akkor kifelé igyekszik, de ha a településen belül akar elérni valamit ugyanazon az úton haladva, akkor lefelé megy (HEINRICH 2000: 26).

Amennyiben ugyanakkor a határt valamilyen mesterséges vagy természetes objektum testesíti meg, akkor az természetszerüen sokkal határozottabban van jelen az emberek kognitív térképén, illetve annak jellemzően nevet is adnak, és a határról való beszéd során 
ezzel utalnak magára a határra is. Ez lényegében ugyanazzal a kognitív müködéssel magyarázható, mint a kiemelkedés és a rajta lévő erdő megnevezése. Ilyen például a berlini fal tulajdonnévi formája: Die Mauer 'Fal', illetve kelet-német hivatalos neve: Antifaschistischer Schutzwall. Ugyanez figyelhető meg a határként funkcionáló folyók esetében is.

Hasonló a helyzet a határpontokkal is: míg a határok elmosódottak, egyes rajtuk lévő pontok nagyon is egyértelműek lehetnek mindenki számára, és jellemzően nevet is kapnak. Ilyen például a Checkpoint Charlie a felosztott Berlinben vagy az ismert határátkelők az országok között, valamint a középkori határjárásokban említett határjelölők. ${ }^{13}$

A határok felfogásában is mutatkoznak ugyanakkor kulturális különbégek: az ausztrál eipók településein például THIERING és SCHIEFENHÖVEL (2016: 61) szerint a faluból kifelé indulva szektorról szektorra haladunk, melyek határai pontosan meghatározottak. Noha maguknak a határoknak nincs nevük, az általuk elkülönített területeknek igen, s a hozzájuk kötődő valós vagy fiktív események is jól ismertek.

A képzeletbeli skála másik végpontjához közel helyezhető az arab kultúra. A határok itt igen bizonytalanul értelmezettek: EDWARD T. HALL kutatásai szerint a városok ,,pereme" létezik, ám a külterületen a földeken nincsenek állandó határok (1995²: 176).

4.2. Központ-periféria szemlélet. Az emberi kogníció egyik alapvető jellemzője, hogy a fogalmi kategóriák prototípuselven épülnek ki, és bizonyos példányok a kategória tipikus elemeinek tekinthetők, míg mások kevésbé vagy csak alig. A fogalmi kategóriákat jellemző központ-periféria szerveződés a tér reprezentációjában is megfigyelhető. Amint ezt már láttuk is, ilyen módon reprezentáljuk a lakott területeket (vö. az eipók településének kiépülését), s ez a szemlélet a térről beszélve is érvényesül. A központ-periféria szerveződés a tér különböző léptékü szemléleteiben egyaránt érvényesül, amint ezt a mentális térképezés módszerét alkalmazó vizsgálatok kimutatták; ez a közelítésmód a helyek méretének megítélését is befolyásolja (vö. LETENYEI 1999). Ez a szemléletmód a nevek viszonyában fontos összetevő. Mivel ez a viszony gyakran az irányokkal összefonódva fejeződik ki nyelvileg, ezért azt tárgyalva még visszatérek rá.

4.3. Irányok. A helyek valamilyen irányban helyezkednek el egymáshoz képest, s ezt szintén reprezentáljuk, illetve a térkép funkciójából adódóan a kommunikáció során is gyakran megjelenik az erre való utalás. Arra pedig, hogy hogyan történik az irányok reprezentációja, hatással van az adott közösségben preferált referenciakeret. A helyzetviszonyítás, az irányok megjelölése ugyanis többféleképpen történhet: az egocentrikus referenciakeret a beszélőhöz viszonyít, az intrinzikus referenciakeret külső dolgokhoz, például utakhoz vagy tájékozódási pontokhoz (a kettő együttesen a relatív referenciakeret), míg az abszolút referenciakeret érvényesítésekor abszolút irányokat, égtájakat alkalmazunk az irányok kifejezésekor (vö. LEVINSON 2003).

A földrajzi térről való beszéd során a nyugati típusú társadalmakban jellemzően az intrinzikus vagy az egocentrikus keretet használják, s a helynevekben is jobbára az intrinzikus kerethez kötődő helyzetviszonyító elemek jelennek meg. Nem állja azonban meg a helyét az a vélekedés, mely szerint ,,az elnevezőnek olyan tapasztalata, hogy valami északi, déli, keleti, vagy nyugati irányban fekszik, nem lehet” (LŐRINCZE 1947: 10).

\footnotetext{
${ }^{13}$ A példákat köszönöm anonim lektoromnak.
} 
Az intrinzikus és egocentrikus keret használatánál ugyanis sokkal ritkábban ugyan, de találkozhatunk az abszolút irányokat alkalmazó allocentrikus térmeghatározással (vö. HEINRICH 2000: 24, HOCHBAUER 2010, GYÖRFFY 2015a: 111), használata ugyanakkor inkább a tágabb környezet leírásában figyelhető meg (MARK et al. 1999: 759, TAYLOR-TVERSKY 1996). A valóságban ez a kétféle közelítésmód sem ennyire egyszerűen különíthető el, találunk példát ugyanis arra, hogy az intrinzikus kerethez kötődő nyelvi elemek akár közszóként, akár helynevek részeként allocentrikus jelentéstartalommal használatosak (vö. BÖLCSKEI 2010: 157). Meglehetősen gyakoriak továbbá a kommunikáció során a perspektívaváltások, általában jelzés nélkül (MARK et al. 1999: 759). ${ }^{14}$

A kognitív szemléletű vizsgálatok szerint azonban a vázolt referenciakeretek mellett egy sajátos, a nyelvi világmodellen alapuló dimenzió (értékjelentés) is érvényesül mind a térszemléletben, mind a helyekről való beszédben és a helynevekben. HEINRICH ANDREA a szaniszlói helyneveket és használatukat vizsgálva mutatta be, hogy a helyiek kognitív térképének FENT-LENT, BENT-KINT, illetve KÖZEL-TÁVOL viszonyai nem a valós vertikalitás vagy horizontalitás szerint szerveződnek, hanem egy hierarchikus viszony szervezi ezek észlelését (központ és periféria; a központ a mienk, az ismert, hozzánk közeli). Ugyanez az elv érvényesül a helyek nagyobb léptékü megközelítésekor, a bel- és a külterületek együttes szemléletekor is: ebben az esetben a falu lesz a FENT, s a határ a LENT. A domborzati formák esetében ugyanakkor a valós vertikalitás szerinti szemlélet is érvényesül: a külterületen lévő dombok szintén FENT-helyek; ezt indokolja egyébként az is, hogy fontos tájékozódási pontnak számítanak (HEINRICH 2000: 34). A szerző arra is felhívja a figyelmet, hogy nyelvi adatai - a gyüjtés sajátosságaiból adódóan - csak a falu felőli nézőpontot tükrözik, noha lehetséges, hogy a nézőpont megváltozása a kognitív térkép müködtetésében is változásokat okozhat (HEINRICH 2000: 3).

A legújabb szocioonomasztikai kutatások is hasonló eredményre jutottak. GYŐRFFY ERZSÉBETtöl tudjuk, hogy a tépeiek a központi helyekröl beszélnek FENT-, illetve BENThelyekként (ezeken belül is elkülöníthetők ugyanakkor fokozatok), míg a LENT és KINT megjelöléssel a periferikusabbnak ítélt helyekre utalnak (2015a: 112). SZILÁGYI-VARGA ZSUZSA Kisbábony kapcsán szintén ezt tárta fel, a cigány és a magyar közösség ugyanakkor ezt részben különböző módon ítéli meg, míg a közösségeken belül nagyfokú hasonlóság tapasztalható (2017a: 186-188).

HEINRICH ezt a jelenséget SzILÁGYI N. SÁNDOR elméletével magyarázza: a szavakhoz, köztük az irányokat jelölő ún. helyzetviszonyító elemekhez is értékjelentések kapcsolódnak, ami e nyelvi elemek sajátos összeszerveződését eredményezi. A pozitív értékjelentésü szavak így asszociációszerúen más pozitív jelentésüekkel kapcsolódnak össze, míg a negatív jelentésűek más negatív jelentésűekkel. ${ }^{15}$ A tényleges iránymegjelölés mellett ez tehát egy

\footnotetext{
${ }^{14}$ Az irányok vonatkozásában a nyelvi elemkészlet mellett az újabb kutatások a nonverbális kommunikáció szerepét is hangsúlyozzák (vö. EMMOREY et al. 2000).

${ }^{15}$ A nyelvi (a beszédünkben megjelenő) világban egy sajátos térstruktúra figyelhető meg, amelyben a nyelvi elemek értékjelentésük szerinti polaritásuknak megfelelöen tömörülnek a nyelvi tér két térfelén (SZILÁGYI N. 1997: 12-13). A szavakhoz kapcsolódó értékjelentések strukturálódását a nyelvvel együtt tanuljuk meg, s ezek tudattalanul hatnak a világ észlelése és a benne való tájékozás során is. A nyelvi világmodell térstruktúrájában a legfontosabb dimenzió a vertikális, a FENT-LENT
} 
sajátos kétpólusúságot eredményez a nyelvi térben. LAKOFF a testben levéssel, illetve ebből adódóan az egész gondolkodásunkat átható metaforikus szemlélettel magyarázza a jelenséget (LAKOFF-JOHNSON 1999, GOSCHLER 2005, GOTTWALD-ELSNER-POLLATOS 2015, TOLCSVAI NAGY 2017: 256-259). Az elméletet pszichológiai vizsgálatok is alátámaszják (vö. pl. MEIER-ROBINSON 2004, LU et al. 2014).

Annak ellenére, hogy úgy tűnik, ez a fajta szemléletmód a kognitív rendszer általános jellemzője, a téri nyelvről szólva mégsem tekinthető univerzálisnak. Ez azonban egyszerüen abból adódik, hogy a helyzetviszonyító elemek állománya kultúránként különbözik. Ismeretes, hogy egyes természeti népek csak az abszolút referenciakeretet ismerik, nyelvükben is csak ez jelenik meg. A kuuk thaayorre ausztrál bennszülött közösség tagjai például a helymegjelölések egész skáláján az égtájak szerinti iránymutatást használják; pl. „Van egy hangya a délebbre lévő lábadon”, vagy üdvözlésnél: „Hová mész?” - „Dél-délkeletre, közepes távolságra" (BORODITSKY 2009). Ehhez hasonló rendszer müködik a mexikói celtál nyelvű népcsoport nyelvhasználatában is, ahol szintén hiányoznak a relatív viszonyok nyelvi megjelölései, s ehelyett egy sajátos, a domborzati viszonyokból adódó DOMBNAK FEL - DOMBRÓL LE ('uphill', 'downhill') viszony szervezi a referenciakeretet. Ez azonban a DÉL-ÉSZAK viszony jelölésére is használatos, $\mathrm{s}$ az erre merőlegesen értelmezett KERESZTÜLlel ('across') kiegészülve abszolút referenciakeretként funkcionál (BROWN 2006: 155-160). Ebben az esetben nyilván nem számolhatunk hasonló szerveződéssel, mint amit a magyar példák mutatnak.

A helyzetviszonyító nyelvi elemek a helynevekben is megjelenhetnek. Különösen jellemző ez a névadási gyakorlat a HOCHBAUER MÁRIA (2008) által vizsgált négyfalusi helynevekre: a településen száznegyven ilyen névszerkezetet gyüjtött a kutató. Ezeket az egyes helyfajták szerint elkülönülten elemezve arra jutott, hogy a tapasztalati világ térbeli dimenziói a nyelvi világban némileg másképpen képződnek le. ${ }^{16}$ A vizsgálat alapján a nyelvi világ a horizontalitást is az értékjelentések szerint szerveződő vertikalitásként érzékeli, s a szemantikai korrelációk tulajdonképpen két pólus köré tömörülnek: ALSÓ-BELSÖ-ELSÖBAL-KICSI-KÖZEL ↔ FELSÖ-KÜLSÖ-HÁTSÓ-JOBB-NAGY-TÁVOL. ${ }^{17}$ Amint látható, még a

ellentéte, amelyhez a szolidáris értékek vonzása folytán rendszerszerüen kapcsolódnak bizonyos más, egymással többé-kevésbé összefüggő értékdimenziók (a pozitív pólus a FENThez, a negatív a LENThez). Ez a szerveződés természetszerűen maguknak a helyzetviszonyító elemeknek az esetében is érvényesül.

${ }^{16}$ Névanyagában ezek a nevek mindig párosával fordulnak elö. A korpuszban az ALATT-FÖLÖTT (alsó-felsö) viszony fejeződik ki a legtöbb helynévben, s majdnem minden helyfajta, köztük horizontális jellegü helyek neveiben is szerepelnek ezek a helyzetviszonyító elemek: a vertikálisan magasan elhelyezkedők mellett gyakorta nagy, tőlünk távol eső, idegen helyeket jelölnek a felső lexémával. Az ALATT-FÖLÖTT viszony tehát mindkét dimenzióban erőteljesen jelen van, és - noha nem a denotatív jelentésük, sokkal inkább az értékjelentésük révén - az összes többi téri viszony is kapcsolatba hozható vele, ezért HOCHBAUER elementáris viszonynak nevezi (2007: 5).

17 HochBAUER MÁRIA (2007: 30-31) tapasztalatai szerint Négyfaluban a helyzetviszonyító elemek vázolt szerveződése olyan mértékben meghatározó, hogy még azt az általános tendenciát is felülírják, mely szerint a folyóvizek ágainak megjelölésekor a folyásiránytól számítják a bal és jobb oldali ágakat: a Tészla jobb ága névforma ugyanis a folyó folyásiránytól számított bal ágát jelöli, míg a Tészla bal ága a folyásiránytól számított jobb oldali ágat. Ez nyilván összefügg azzal, hogy e névformák szinonimája a Tészla felső ága (Tészla jobb ága), illetve a Tészla alsó ága (Tészla bal ága). 
méretre utaló lexémák is illenek ebbe a rendbe. Ugyanakkor egy szembeötlő különbség is megmutatkozik itt a korábbi példákhoz képest. Négyfalu névanyagában a fent lexéma a falutól távol eső, periferikus helyek nevében szerepel, azaz a négyfalusi helynevek eltérnek az értékstruktúra szerveződésének prototipikus formájától (ez talán a domborzati viszonyokkal magyarázható). A helyzetviszonyító elemek Négyfaluban tapasztalt komplex összefonódása unikálisnak tünik, s a dolgozatból nem tudjuk meg, hogy ez a térről való beszédet általában véve befolyásolja-e. Ennek kapcsán az is kérdéses, hogy az érintett helynevek mennyire ismertek, erre vonatkozóan azonban nincsenek adatok. Mindenesetre PESTI JÁNOS vizsgálatai szerint ilyenfajta eltérés másutt is akad a magyar helynévanyagban (1969: 230-231), ám ö inkább a lexémák komplex szemantikai szerkezetével magyarázza ezt. A nevekben e szavak a következő jelentésekben állnak: a) domborzati, azaz lényegében kvázivertikális viszonyra utalás (alsó 'mélyen fekvő' - felsö 'magasan fekvő'); b) folyóvizek folyásirányára utalás; c) a felszín horizontális tagolódására utalás (alsó 'közelebb eső' - felsö 'távolabb eső'; alsó 'valaminek a vége, határa' - felsö 'valaminek a középpontja'); d) településtörténeti, néprajzi vonatkozásokra utalás (pl. alvég 'cigányok lakta falurész'); e) égtájakra utalás (alsó 'déli' - felsö 'északi'); ezek a jelentések sok esetben kombinálódnak (PESTI 1969: 230-231, további lehetséges jelentésekhez - pl. településrészekre vagy korra utalás, ti. korábbi és újabb település - vö. KÁZMÉR 1970: 37, MEZÖ 1982: 223, BÖLCSKEI 2010: 157-158).

A helyzetviszonyító elemek kapcsán a nevekben, illetve a helyekröl való beszédben tapasztalt összeszerveződés általános jellegének megállapításához a magyar mellett más nyelvek névrendszerét, illetve névhasználati sajátosságait is meg kell vizsgálni, ilyen jellegü elemzésekröl azonban nincs tudomásom. HOCHBAUER MÁRIA ugyanakkor Négyfalu román névanyagát is elemezte, $\mathrm{s}$ azt tapasztalta, hogy a magyar-román névpárok gyakran tükörfordítások, azaz szoros kapcsolat van közöttük. A románban azonban jóval több helyet neveznek 'kicsi/nagy'-nak, míg a magyarban ezek gyakorta alsó/felsö helyzetviszonyító elemmel szerepelnek (2007: 32-33). Ez a KICSI-NAGY ellentétpár téri helyzetviszonyító elemként való használatának általánosabb jellegét - s egyúttal a fenti, a helyzetviszonyító elemek értékjelentés szerinti szerveződésére vonatkozó megállapítás univerzális jellegét - látszik támogatni. Ez azonban további megerösítést igényel (mind az adott területen, mind általánosabban, azaz hogy másutt találunk-e példát hasonló jelenségre), az idézett példák ugyanis a magyar nevek tükörfordításának analógiás hatásával, illetve a kétnyelvüséggel, a két névrendszer egymásra hatásával is magyarázhatók.

4.4. Távolságok. Az egyének a helyek egymáshoz viszonyított távolságát is rögzítik a mentális rendszerükben különböző léptékekben, a távolságérzetet azonban több tényező is befolyásolja (például a kanyarok száma, vö. MCCORMACK et al. 2007; a helyekhez kapcsolódó értékítéletek, az ott élőkröl alkotott sztereotípiák, vö. MICHALKÓ 2008: 100-101; 1. még POREISZ 2013). Ennek eredményeképpen a kognitív térképen a távolságok gyakran torzításokkal reprezentálódnak (szubjektív távolságreprezentáció vagy kognitív távolság). ${ }^{18}$ A távolságviszonyok érzékelésének szubjektív jellege a kommunikáció során is megjelenik, s mint láttuk, a KÖZEL-TÁVOL viszonyok értelmezését is meghatározzák a hozzájuk

\footnotetext{
${ }^{18}$ A távolságbecslés nem csak a metrikus rendszerre támaszkodva történhet: utazási időként is megközelíthető, illetve - különösen a turizmusban - költséggé is konvertálódhat (vö. MicHALKÓ 2008: 118-121).
} 
kapcsolódó értékjelentések, melyek alapján gyakran összefonódnak az irányt jelölő szavakkal. HOCHBAUER MÁRIA (2007: 27-28) megfigyelése szerint az értékdimenziók Négyfaluban a helyekről való beszéd egyéb sajátosságait is szervezik: a közeli helyekről ugyanis egyik adatközlője mindig közelre mutató névmást, illetve jelen időt használva beszélt, míg a távolabbi, magasabb helyekről távolra mutató névmással, illetve szinte végig múlt időt használva. A távolságnak a térről való beszédben, illetve a helynevekben való megjelenéséről azonban az idézett dolgozatot leszámítva alig van ismeretünk. Nincs információnk arról, hogy más kultúrákban hogyan értelmeződnek és nyelvileg hogyan jelennek meg a távolságviszonyok, illetve hogy általános-e ezen lexémák helynevekben való megjelenése.

A távolságok persze több szinten értelmezhetök. A saját tapasztalatból ismert környezeten túl a más forrásból származó információk is beépülnek a kognitív térképbe. Ez nyilvánvalóan a távolságok reprezentációjára is hatással van. A másodlagos információforrások mellett a modern társadalmak esetében ugyanakkor - az utazás lehetőségeinek kiszélesedésével - a saját tapasztalattal felfedezhető helyek köre is kitágult. Ebböl adódóan alapvető különbség jelentkezik a természeti népek és a modern társadalmak között a kognitív térkép által felölelt információk és a térkép által lefedett terület szempontjából. A természeti népeknél a földrajzi környezet az élet szerves része, behatóan ismerik. A téri ismeretek ugyanakkor más oldalról behatároltak: a saját tapasztalaton, illetve a közösség tapasztalatán túli területekről nem vagy alig lehet ismeretük. A hegyekben gazdag területen élő ausztrál eipók saját tapasztalatból származó földrajzi ismerete például $\mathrm{kb}$. három napos gyors gyaloglással bejárható területre terjedt ki (THIERING-SCHIEFENHÖVEL 2016: 63). A vándorló életmódot folytató nomád közösségekben már lényegesen nagyobb ez a terület, de még mindig erősen korlátozott; a közösség életmódja és a természeti viszonyok egyaránt meghatározók ebből a szempontból. Ezzel szemben a modern társadalmakban az egyéneknek az egész földröl van valamiféle vázlatos képük, ismeretrendszerük, és jól ismerik a közvetlen környezetüket is, ez azonban jobbára városi környezet.

4.5. Rész-egész, egész-rész, rész-rész viszonyok. A kognitív térkép a helyek további viszonyairól is tartalmaz információkat. Az ember ugyanis - sajátos térszemléletéből adódóan - igen gazdagon strukturálja a lokális viszonyokat: a legnagyobb területek kisebb részekre tagolódhatnak, s ez, valamint a szomszédosságról, a lokális érintkezésről való tudás szintén megjelenik a kognitív térképen. Az ember tehát „többszintű, összetett, hierarchikus rendszert alakít ki” a környezetéröl (HoFFMANN 1993: 98-99), azaz a helyek reprezentációi egy sajátos alá-fölé, valamint mellérendeltségi viszonyban állnak egymással. Emellett a felismert téri érintkezések is reprezentálódnak, vagyis a valóságban a tapasztalat szerint egymás mellett elhelyezkedő téri objektumok a fogalmi térben is közel képeződnek le. E viszonyok felismerésének és müködtetésnek hátterében olyan általános kognitív képesség, a metonímia áll, melynek révén képesek vagyunk az egymással valamilyen módon kontiguitásban lévő dolgok, fogalmak között asszociációkat alkotni, és egyikből következtetni a másikra. (A kognitív nyelvészet szerint a metonímia nem csupán nyelvi eszköz, hanem a mindennapi viselkedésünk, gondolkodásmódunk és beszédünk egyik általános jellemzője [vö. LAKOFF-JOHNSON 1980: 37, RESZEGI 2011: 80], a tényleges mentális, illetve idegrendszeri mechanizmusai ugyanakkor még nem egyértelmüek.) 
A helyek rész-egész, rész-rész, illetve térben érintkező viszonyai gyakran az elnevezésekben is tükröződnek; ennek jellegzetes példája a névbokrok kialakulása. Névbokrosodásnak nevezik a hazai szakirodalomban azt a metonimikus szemléleten alapuló névadási folyamatot, amelynek során ,,a meglévő helynevek újbóli felhasználásával jönnek létre a rendszer újabb elemei” (vö. KOCÁN 2017: 201). Az egymással lokális kapcsolatban álló helyek megnevezésére tehát nem ritkán az egyik, már névvel jelölt száliens objektum nevét használják fel, s különféle névalkotási módokkal ebböl kiindulva hoznak létre névformákat. Az Ugocsa megyei Batár víznév például számos, a patakkal kapcsolatban álló különböző hely nevében megjelenik: Batár falu, Holt-Batár, Batár-hát, Batár-part, Batár-szeg (KOCÁN 2017: 203-204).

A rész-egész viszonyok sajátos szerveződése figyelhető meg a japán földterületek megnevezésében is. A falvak határában az egy öntözési rendszerbe tartozó rizsföldek nevei közösségi szinten ismertek, ezek szerepelnek a kataszteri térképeken. Ezek a földterületek számos kisebb területre oszlanak, amelyek azonban csak a területtel foglalkozók számára ismertek. E részek is kapnak neveket (plot names), még ha nem is tekintik őket valódi tulajdonneveknek, mivel nem ismertek széles körben (IMAZATO 2013). E kisebb egységek neveiben is megjelenhet az egész terület neve, jellemzően valamilyen helyzetviszonyító lexémával összekapcsolva (IMAZATO 2014: 29-33). Ez a névadási mód a magyar névanyagban is igen általános (vö. a településnevek kapcsán BÖLCSKEI 2010).

A beszélőknek a helyek, illetve ezzel összefüggésben a helynevek ilyenfajta összeszerveződéséről szintén van tudásuk. Ezt szemlélteti GYÖRFFY ERZSÉBET (2015b: 32) tépei példája: az adatközlők a Bika-legelö, Bika-kút, Bika-erdö nevek ismeretében, illetve a nevek által jelölt objektumok egymás melletti elhelyezkedéséröl tudva a számukra ismeretlen, esetleg csak hallomásból ismert, de azonos előtagú Bika-zug nevet is ezek mellé lokalizálták, noha a névvel jelölt hely nem ott fekszik. Szintén a nevek összefüggéseiről való tudást példázza, hogy a szalárdi adatközlök a korábban nem ismert Dóci-rét és Szíki-kút neveket automatikusan a szomszédos település közelébe lokalizálták abból a tudásukból kiindulva, hogy a Dóci és a Szíki családok ott élnek (SZILÁGYI-VARGA 2018).

A már meglévő helynév, névelem új névben való felhasználása, illetve a lokális viszony tükröztetése csak egy a sok lehetséges névadási motiváció és névalkotási mód közül, s noha ismeretes, hogy a magyar névrendszerben igen meghatározó, arról egyelöre keveset tudunk, hogy más kultúrákban mennyire jellemző.

5. Összegzés. Az idézett vizsgálatok egyre inkább afelé mutatnak, hogy az emberek kognitív térképének kiépülését számos körülmény irányítja. A földrajzi környezettel kapcsolatos saját tapasztalatok mellett jelentős a más forrásokból származó, illetve az ezek kombinációjának eredményeként beépülő földrajzi ismeretek aránya is. Ezzel összefüggésben az egyén földrajzi fogalmi készletét, s áttételesen a térszemléletét is befolyásolja a nyelvi-kulturális háttér.

Vannak ugyanakkor általános(nak tünő) jegyek, a kogníció müködési mechanizmusaiból adódó szervezőelvek a tér szemléletében, melyek a mentális térkép kiépülésére, illetve a névadásra is hatással vannak. Ilyen például, hogy az ember ,egy adott helyet csak más helyhez való viszonyában” tud meghatározni (HOFFMANN 1993: 58), s ez a viszonyítás gyakran a helynevekben is tükrözödik. Ezzel szorosan összefügg a tér központ-periféria szemlélete, amely a helyekről való beszédben, s esetenként a helyek nevének jelentéstartalmában is jelentkezik. Szintén általános jegyként említhető, hogy a szavakhoz értékjelentés 
kapcsolódik, s ez mind a térről való beszéd szervezésében, mind a helynevekben megjelenik. Ezek az egymással is érintkező elvek területenként, közösségenként, kultúránként különbözöképpen juthatnak érvényre.

Reményeim szerint a fenti áttekintés jó kiindulási alapot nyújt az ilyen irányú vizsgálatokhoz, s a vázolt leírási keret is eredményesen alkalmazható lesz majd a kognitív térkép működésére és a helynévadás-helynévhasználat sajátosságaira irányuló kutatásokban.

\section{Hivatkozott irodalom}

APORTA, Claudio é. n. [2003]. Inuit orienting. Traveling along familiar horizons. Sensory Studies. https://www.sensorystudies.org/inuit-orienting-traveling-along-familiar-horizons/

APORTA, Claudio 2009. The trail as home. Inuit and their pan-Arctic network of routes. Human Ecology 37: 131-146. https://doi.org/10.1007/s10745-009-9213-x

Aubert Antal 2014. A turizmus földrajza. In: Tóth JózSEF - Vuics TiBor szerk., Általános társadalomföldrajz 1-2. Dialóg Campus Kiadó - Nordex Kft., Budapest-Pécs. 2: 143-159.

BARNHARDT, RAY 2005. Indigenous knowledge systems and Alaska Native ways of knowing. Anthropology \& Education Quarterly 36: 8-23. https://doi.org/10.1525/aeq.2005.36.1.008

BAUKo JÁNOS 2015. Bevezetés a szocioonomasztikába. Nyitrai Konstantin Filozófus Egyetem Középeurópai Tanulmányok Kara, Nyitra.

BORODITSKY, LERA 2009. How does our language shape the way we think? https://www.edge. org/ conversation/lera boroditsky-how-does-our-language-shape-the-way-we-think (2017. 04. 18.)

BÖLCSKEI ANDREA 2010. A magyar településnevek korrelációs rendszerének alakulása a természetes névadás korszakában. A Károli Gáspár Református Egyetem Magyar Nyelvtudományi Tanszékének Kiadványai 2. Károli Gáspár Református Egyetem Magyar Nyelvtudományi Tanszéke, Budapest.

Brown, PENELOPE 2006. Up, down, and across the land. Landscape terms, place names, and spatial language in Tzeltal. Language Sciences 30: 151-181. https://doi.org/10.1016/j.langsci.2006.12.003

BRÓZIK PÉTER - KESZEI BORBÁLA - DÚLL ANDREA 2019. Mentális térképezés a köztérkutatásban. Két környezetpszichológiai vizsgálat kutatásmódszertani tapasztalatai. socio.hu 2019/1: 19-47. https://doi.org/10.18030/socio.hu.2019.1.19

BuCHNER, AXEL - JANSEN-OSMANN, PETRA 2008. Is route learning more than serial learning? Spatial Cognition and Computation 8: 289-305. https://doi.org/10.1080/13875860802047201

BuRENHUlt, NiCLAS 2005. Landscape terms and toponyms in Jahai. A field report. Working Papers 5: $17-29$

Burenhult, Niclas - Levinson, StePhen C. 2008. Language and landscape. A cross-linguistic perspective. Language Science 30: 135-150. https://doi.org/10.1016/j.langsci.2006.12.028

Cogos, SARAH - Roué, MARIE - Roturier, SAMUel 2017. Sami place names and maps. Transmitting knowledge of a cultural landscape in contemporary contexts. Arctic, Antarctic, and Alpine Research 49: 43-51. https://doi.org/10.1657/AAAR0016-042

Collignon, BeAtrice 2006. Inuit place names and sense of space. In: Stern, PAmela - Stevenson, LisA eds., Critical Inuit Studies. An Anthology of Contemporary Arctic Ethnography. University of Nebraska Press, Lincoln-London. 187-205.

CsÉFALVAy ZolTÁN 1990. Térképek a fejünkben. Akadémiai Kiadó, Budapest.

Downs, Roger M. - STEA, DAVID 2006. Térképek az elmében. Gondolatok a kognitív térképezésről. (Részletek). In: LETENYEI LÁszLÓ szerk., Településkutatás 1-2. TeTT könyvek, Budapest. 2: 593-613. 
EMmorey, KAREN - TVERSKy, BARBARA - TAYlor, Holly A. 2000. Using space to describe space. Perspective in speech, sign, and gesture. Spatial Cognition and Computation 2: 157-180. https://doi.org/10.1023/A:1013118114571

ENFIELD, NicK J. 2008. Linguistic categories and their utilities. The case of Lao landscape terms. Language Sciences 30: 227-255. https://doi.org/10.1016/j.langsci.2006.12.030

Epstein, Russell A. - Patai, Eva Zita - Julian, Joshua B. - Spiers, Hugo J. 2017. The cognitive map in humans: spatial navigation and beyond. Nature Neuroscience 20: 1504-1513. https://doi. org/10.1038/nn.4656

ERNST, PETER 2005. Wörter und Namen im mentalen Lexikon. Namenkunde und kognitive Linguistik. In: Brendler, ANDREA - Brendler, Silvio eds., Namenforschung morgen. Ideen, Perspektiven, Visionen. Baar, Hamburg. 37-44.

Fowler, CATHERINE S. - TurNer, NANCY J. 1999. Ecological/cosmological knowledge and land management among hunter-gatherers. In: LeE, RiCHARD B. - DALy, RichARD eds., The Cambridge Encyclopedia of Hunters and Gatherers. Cambridge University Press, Cambridge. 419-425.

Garde, MurRay 2014, Doing things with toponyms. The pragmatics of placenames in Western Arnhem Land. In: Clark, IAN D. - Hercus, Luise - Kostanski, Laura eds., Indigenous and minority placenames: Australian and international perspectives. ANU ePress. 97-121. https:// doi.org/10.22459/IMP.04.2014.06

GOSCHLER, JULIANA 2005. Embodiment and body metaphors. metaphorik.de 9: 33-52.

Gottwald, Janna M. - Elsner, Birgit - Pollatos, Olga 2015. Good is up. Spatial metaphors in action observation. Frontiers in Psychology 6: 1605. https://doi.org/10.3389/fpsyg.2015.01605

GYÖRFFY ERZSÉBET 2015a. A mentális térképezés helynév-szociológiai alkalmazásáról. Névtani Értesitö 37: 99-117.

GYÖRFFY ERZSÉBET 2015b. A helynévismeretről. Magyar Nyelvjárások 53: 5-33.

GYÖRFFY ERZSÉBET 2017. Helynévismeret és névközösség. Helynévtörténeti Tanulmányok 13: 155-169.

GYÖRFFY ERZSÉBET 2018. Egy online helynévkompetencia-felmérés tanulságai. Magyar Nyelvör 142: 73-84.

HAJDÚ ZolTÁN 2015. A Kárpát-medence geopolitikai helyzete. In: FÁBIÁN ATTILA szerk., Otthon a Kárpát-medencében. Területfejlesztési Szabadegyetem 2011-2015. Nyugat-magyarországi Egyetem Kiadó, Sopron. 45-72.

HALL, EDWARD T. 1995³. Rejtett dimenziók. Katalizátor Iroda, Budapest.

HeINRICH ANDREa 2000. Szaniszló helynevei kognitiv nyelvészeti megközelitésben. Szakdolgozat. Babeş-Bolyai Tudományegyetem BTK, Kolozsvár.

HENZI, MARTINA 2017. Mapping and GIS analysis of place names along the Sonora coast in Mexico. Szakdolgozat. Department of Geography, University of Zurich, Zurich. https://www.geo.uzh.ch/ dam/jcr:44faf4ce-e5fd-4d6a-ad2c-87bd1584b3a0/Master Thesis Martina Henzi 2017.pdf

HirTLE, StePhen C. - HudSON, Judith 1991. Acquisition of spatial knowledge for routes. Journal of Environmental Psychology 11: 335-345. http://dx.doi.org/10.1016/S0272-4944(05)80106-9

HochBauer MÁria 2007. Helyzetviszonyitó elemek a barcasági Négyfalu helyneveiben. Szakdolgozat. Babeş-Bolyai Tudományegyetem BTK, Kolozsvár.

HochBAUER MÁRIA 2008. Helyzetviszonyító elemek a barcasági Négyfalu helynévrendszerében. In: BölCSKeI ANDREA - N. CsÁszi Ildikó szerk., Név és valóság. A VI. Magyar Névtudományi Konferencia elöadásai (Balatonszárszó, 2007. június 22-24). A Károli Gáspár Református Egyetem Magyar Nyelvtudományi Tanszékének Kiadványai 1. Károli Gáspár Református Egyetem Magyar Nyelvtudományi Tanszéke, Budapest. 164-169. 
HOCHBAUER MÁRIA 2010. Tér- és nyelvhasználat a mindennapi tájékozódásban. Magyar Nyelvjárások 48: $99-110$

HofFMANN IsTVÁN 1993. Helynevek nyelvi elemzése. A Kossuth Lajos Tudományegyetem Magyar Nyelvtudományi Intézetének Kiadványai 61. Kossuth Lajos Tudományegyetem Magyar Nyelvtudományi Intézete, Debrecen.

HOFFMANN ISTVÁN 2010. Víznevek a Kárpát-medencében. Hidak nyelvek és kultúrák között. In: BARTHA ELEK - KemÉnyfi Róbert - Lajos VeroniKa szerk., A viz kultúrája. Debreceni Egyetem Néprajzi Tanszék, Debrecen. 209-220.

HoFFMANN ISTVÁN 2012. Funkcionális nyelvészet és helynévkutatás. Magyar Nyelvjárások 50: 9-26.

HOFFMANN ISTVÁN - RÁCZ ANITA - TÓTH VALÉRIA 2018. Régi magyar helynévadás. A korai ómagyar kor helynevei mint a magyar nyelvtörténet forrásai. Gondolat Kiadó, Budapest.

Holton, GARY 2011a. Landscape in Western Pantar, a Papuan outlier of southern Indonesia. In: Mark, David M. - Turk, ANDrew G. - Burenhult, Niclas - Stea, David eds., Landscape in Language: Transdisciplinary Perspectives. Culture and Language Use 4. John Benjamins Publishing Company, Amsterdam-Philadelphia. 143-166. https://doi.org/10.1075/clu.4.08hol

Holton, GARY 2011b. Differing conceptualizations of the same landscape. The Athabaskan and Eskimo language boundary in Alaska. In: MARK, DAVID M. - TuRK, ANDREW G. - Burenhult, NiClAS - STEA, DAVID eds., Landscape in Language: Transdisciplinary Perspectives. Culture and Language Use 4. John Benjamins Publishing Company, Amsterdam-Philadelphia. 221-237. https://doi.org/10.1075/clu.4.11hol

IMAZATO, SATOSHI 2013. Naming methods of folk agricultural plot names in Japanese villages. A connection between geography and cognitive linguistics. Semestrale di Studi e Ricerche di Geografia 25: 27-39.

Jett, Stephen C. 1997. Place-naming, environment, and perception among the Canyon de Chelly Navajo of Arizona. Professional Geographer 49: 481-493.

JetT, StePhen C. 2011. Landscape embedded in language. The Navajo of Canyon de Chelly, Arizona, and their named places. In: MARK, DAVID M. - TuRK, ANDREW G. - BURENHUlt, Niclas - SteA, David eds., Landscape in Language. Transdisciplinary Perspectives. Culture and Language Use 4. John Benjamins Publishing Company, Amsterdam-Philadelphia. 327-342. https://doi.org/10.1075/clu.4.16jet

KARI, JAMES 1989. Some principles of Alaskan Athabaskan toponymic knowledge. In: KEY, MARY Ritchie - Hoenigswald, Henry M. eds., General and Amerindian Ethnolinguistics. In Remembrance of Stanley Newman. Mouton de Gruyter, Berlin - New York. 129-149. https://doi.org/ 10.1515/9783110862799-014

KARI, JAMES 2003. Dena' ina place names and territorial knowledge. In: KARI, JAMES - FALL, JAMES A. Pete, Shem - Alex, Mike eds., Shem Pete's Alaska. The Territory of the Upper Cook Inlet Dena' 'ina. University of Alaska, Fairbanks. 30-48.

KÁzMÉr MikLós 1970. A „falu” a magyar helynevekben. XIII-XIX. század. Nyelvészeti Tanulmányok 13. Akadémiai Kiadó, Budapest.

KoCÁN BÉLA 2017. Helynévtörténeti vizsgálatok a régi Ugocsa megyében. A Magyar Névarchívum Kiadványai 43. Debreceni Egyetemi Kiadó, Debrecen.

KUIPERS, BENJAMIN 1982. The "map in the head" metaphor. Environment and Behavior 14: 202-220.

LAKOFF, GEORGE - JohnSON, MARK 1980. Metaphors We Live By. The University of Chicago Press, Chicago-London.

LAKoff, GeOrge - Johnson, MARK 1999. Philosophy in the Flesh. The Embodied Mind \& its Challenge to Western Thought. Basic Books, New York. 
LANGACKER, RonALD W. 2008. Cognitive Grammar. A Basic Introduction. Oxford University Press, Oxford.

LASHLEy, Karl S. - BALl, Josephine 1929. Spinal conduction and kinesthetic sensitivity in the maze habit. Journal of Comparative Psychology 9: 71. https://doi.org/10.1037/h0071239

LÁszló, Ervin - Masuli, IgNAZio - ARTigiani, RoberT - CsÁNYi, Vilmos eds. 19952. The Evolution of Cognitive Maps. New Paradigms for the Twenty-First Century. Gordon and Breach Publishers, Langhorn (PA).

LETENYEI LÁsZló 1999. A falusi társadalom rejtett kapcsolatai. In: Borsos ENDRE - CSITE ANDRÁS - LETENYEI LÁsZLó szerk., Rendszerváltozás után: falusi sorsforduló a Kárpát-medencében. Számalk, Budapest. 113-148.

LeVinson, STEPHEN C. 2003. Space in Language and Cognition. Exploration in Cognitive Diversity. Cambridge University Press, Cambridge.

LeVinson, StePhen C. 2008. Landscape, seascape and the ontology of places on Rossel Island, Papua New Guinea. Language Sciences 30: 256-290. https://doi.org/10.1016/j.langsci.2006.12.032

LÖRINCZE LAJOS 1947. Földrajzineveink élete. Teleki Pál Tudományos Intézet Néptudományi Intézete, Budapest.

Lu, AitaO - Yu, YanPing - Zhang, MeichaO - Chang, Lei - Liang, Bishan 2014. Occupational stereotype. Up-down spatial embodiment of the competence content. Psychologia 57: 1-11. https://doi.org/10.2117/psysoc.2014.1

Lynch, KeVIn 1960. The imagine of the city. The MIT Press, Cambridge (MA) - London.

Mark, David M. - Freksa, Christian - Hirtle, C. Stephen - Lloyd, Robert - Tversky, BARBARA 1999. Cognitive models of geographical space. International Journal of Geographical Information Science 13: 747-774. https://doi.org/10.1080/136588199241003

MARK, DAVID M. - TURK, ANDREw G. 2003. Landscape categories in Yindjibarndi: Ontology, environment, and language. In: KUHN, Werner - WORBOys, MichaEl F. - TimPF, SABINE eds., Proceedings of 03' Conference of Spatial Information Theory. Springer, Heidelberg. 31-49. https://doi.org/10.1007/978-3-540-39923-0 3

Mark, David M. - Turk, Andrew G. - Burenhult, Niclas - Stea, David 2011. Landscape in language. An introduction. In: Mark, David M. - TurK, ANDREW G. - BurenhUlt, Niclas STEA, DAVID eds., Landscape in Language: Transdisciplinary Perspectives. Culture and Language Use 4. John Benjamins Publishing Company, Amsterdam-Philadelphia. 1-24. https://doi.org/ $\underline{10.1075 / \text { clu. } 4.02 \mathrm{mar}}$

Mark, David M. - TurK, AndRew G. - Burenhult, Niclas - Stea, David eds. 2011. Landscape in Language: Transdisciplinary Perspectives. Culture and Language Use 4. John Benjamins Publishing Company, Amsterdam-Philadelphia. https://doi.org/10.1075/clu.4

MARK, M. DAVID - TURK, ANDREW G. - STEA, DAVID 2011. Ethnophysiography. In: MARK, David M. - Turk, Andrew G. - Burenhult, Niclas - Stea, David eds., Landscape in Language: Transdisciplinary Perspectives. Culture and Language Use 4. John Benjamins Publishing Company, Amsterdam-Philadelphia, 25-46. https://doi.org/10.1075/clu.4.03tur

McCormack, Gavin R. - Cerin, Ester - Leslie, Eva - Du Toit, Lorinne - Owen, Neville 2007. Objective versus perceived walking distances to destinations. Correspodence and predictive validity. Environment and Behaviour 40: 401-425. https://doi.org/10.1177/0013916507300560

Meier, Brian P. - Robinson, Michael D. 2004. Why the sunny side is up. Assotiations between affect and vertical position. Psychological Science 15: 243-247. https://doi.org/10.1111/j.09567976.2004.00659.x 
MEZỎ ANDRÁs 1982. A magyar hivatalos helységnévadás. Nyelvészeti Tanulmányok 22. Akadémiai Kiadó, Budapest.

MichALKÓ GÁBOR 2008. A turisztikai tér társadalomföldrajzi értelmezésének új dimenziói. Akadémiai doktori értekezés. MTA Földrajztudományi Kutatóintézet, Budapest.

MugereZI, EdwIN 2002. An Environmental Management Information System (Emis) for Iringa Municipality, Tanzania Implementation Challenges. The International Archives of the Photogrammetry, Remote Sensing and Spatial Information Sciences 34. Part 6/W6: 78-86. https://pdfs. semanticscholar.org/2281/111e262ba1b05f70c3c1083d798ad6c40678.pdf

E. NAGY KATALIN 2015. Helynév-szociológiai vizsgálatok két Hajdú-Bihar megyei településen. Magyar Nyelvjárások 53: 35-45.

Pesti JÁNOS 1969. Földrajzi neveink alsó-, felsö- ( al-, fel-) helyzetviszonyító elemei. Magyar Nyelvör 93: 229-231.

PINNA, BAINGIO 2010. New Gestalt principles of perceptual organization. An extension from grouping to shape and meaning. Gestalt Theory 32: 1-67.

PorEISZ VERONIKA 2013. Az objektív és szubjektív térérzékelés vizsgálatának lehetséges módszerei. In: KARLOVICZ, JÁNOS TiBOR szerk., Ekonomické štúdie - teória a prax (Gazdasági tanulmányok - elmélet és gyakorlat). International Research Institution, Komárno. 369-376.

Reszegi KATALIN 2008. A hegynév terminus definiálása. In: BölCSKEI ANDREA - N. CsÁszi ILDikó szerk., Név és valóság. A VI. Magyar Névtudományi Konferencia előadásai (Balatonszárszó, 2007. június 22-24). A Károli Gáspár Református Egyetem Magyar Nyelvtudományi Tanszékének Kiadványai 1. Károli Gáspár Református Egyetem Magyar Nyelvtudományi Tanszéke, Budapest. 240-246.

Reszegi Katalin 2009. A kognitív szemlélet lehetőségei a helynévkutatásban. A metonimikus névadás. Magyar Nyelvjárások 47: 21-41.

ResZegi KATALIN 2011. A metonímia megítélésének kérdéséhez. In: NAVRACSICS JUDIT szerk., Lexikai folyamatok egy-és kétnyelvü közegben. Pszicholingvisztikai tanulmányok 2. Tinta Könyvkiadó, Budapest. 75-83.

ResZegi KATALIN 2012. A mentális térkép és a helynevek. In: NAVRACSiCs JudiT - LENGYel Zsolt szerk., A mentális folyamatok a nyelvi feldolgozásban. Pszicholingvisztikai tanulmányok 3. Segédkönyvek a nyelvészet tanulmányozásához 140. Tinta Könyvkiadó, Budapest. 95-100.

RESZEGI KATALIN 2015. A névközösség fogalmáról. Névközösségek napjainkban és a régiségben. Helynévtörténeti Tanulmányok 11: 165-176.

ResZeGi KATALIN 2018. Helynevek - térszemlélet - mentális térkép. A nyelv, a helynevek és a tér összefüggései. Magyar Nyelv 114: 169-184. https://doi.org/10.18349/MagyarNyelv.2018.2.169

RESZEGi KATALin megj. e. Cognitive maps and toponyms in a broadening geographical horizon. Megjelenés előtt.

RÉTHY ERZSÉBET 1989. Doboz belterületének és határának földrajzi nevei. A Békés Megyei Múzeumok Közleményei 14: 264-292.

RIEGer, MARIE A. 2014. From Kaiserstraße to Barabara ya Bandarini. What Swahili street names can tell us about the past. In: Tort i Donada, JoAn - Montagut i Montagut, MontSERRAT eds., Els noms en la vida quotidiana. Actes del XXIV Congrés Internacional d'ICOS sobre Ciències Onomàstiques. / Names in daily life. Proceedings of the XXIV ICOS International Congress of Onomastic Sciences. Generalitat de Catalunya, Barcelona. Secció 7: 1670-1684. https://doi.org/10.2436/15.8040.01.172 
Siegel, AleXAnder W. - White, Sheldon H. 1975. The development of spatial representations of large-scale environments. Advances in Child Development and Behavior 10: 9-55. https:// doi.org/10.1016/S0065-2407(08)60007-5

SJÖBLOM, PAULA 2006. A cognitive approach to the semantics of proper nouns. Onoma 41: 63-82. https://doi.org/10.2143/ONO.41.0.2119611

SLíz MARIANN 2012. Tulajdonnév és kategorizáció. Magyar Nyelv 108: 282-291, 400-410.

SZILÁGYI N. SÁNDOR 1997. Hogyan teremtsünk világot? Rávezetés a nyelvi világ vizsgálatára. Erdélyi Tankönyvtanács, Kolozsvár.

SZILÁGYI-VARGA ZSUZSA 2017a. Kisbábony. Egy aprófalu belterületi helynevei és mentális településmorfológiája. Helynévtörténeti Tanulmányok 13: 171-191.

SZILÁGYI-VARGA ZsUZSA 2017b. A kisbábonyi magyarság helynévismerete. Magyar Nyelvjárások 55: 75-109.

SzilágYi-VARga Zsuzsa 2018. Helynév-szociológiai felmérések Szalárdon. Elöadás a Magyar Nyelvtudományi Társaság Debreceni Csoportjának ülésén, Debrecen, 2018. április 12.

TAylor, Holly A. - TVersky, Barbara 1996. Perspective in spatial descriptions. Journal of Memory and Language 35: 371-391. https://doi.org/10.1006/jmla.1996.0021

THIERING, MARTIN 2012. Spatial mental models and common sense geography. In: GeUs, Klaus THIERING, MARTIN eds., Common Sense Geography and Mental Modelling. Max Planck Institute for the History of Science, Berlin. 11-44.

ThIERING, MARTIN - SCHIEFENHÖVEL, Wulf 2016. Spatial concepts in non-literate societies. Language and practice in Eipo and Dene Chipewyan. In: Schemmel, Matthias ed., Spatial Thinking and External Representation. Towards a Historical Epistemology of Space. Max Planck Research Library for the History and Development of Knowledge, Studies 8. Max Planck Institute for the History of Science, Berlin. 35-92.

TolCSVAi NAGY GÁBOR 2017. Jelentéstan. In: TolCSVAI NAGY GÁBOR szerk., Nyelvtan. Osiris Kiadó, Budapest. 207-466.

Tolman, EdWARD C. 1948. Cognitive maps in rats and men. Psychological Review 55: 189-208.

TVERSKY, BARBARA 1993. Cognitive maps, cognitive collages, and spatial mental models. In: Frank, ANDREW U. - CAMPARI, IRENE eds., Spatial Information Theory. A theoretical basis for GIS. European Conference, COSIT'93 Marciana Marina, Elba Island, Italy September 19-22, 1993.Proceedings. 14-24. https://doi.org/10.1007/3-540-57207-4_2

RESZEGI KATALIN

ORCID: https://orcid.org/0000-0002-4443-3284

Debreceni Egyetem

Bölcsészettudományi Kar

\section{KATALIN RESZEgI, The cognitive map and the use of names}

In this paper, the author attempts to provide a general summary of the relationship between the cognitive map and spatial concepts on the one hand, and between the onomasticon related to the cognitive map and discourses about space on the other hand, focusing on universal as well as culturally specific features. To this end, the author summarizes and interprets all the relevant results of national and international research from the areas of geography, socio-geography, anthropology, psychology, socio-onomastics and cognitive linguistics. Space is made up of different places and 
their relationships, which are represented on the cognitive map. At the same time, the development of the cognitive map is governed by many factors. In addition to one's own experiences of the geographical environment. A significant proportion of geographic knowledge also results from different sources or from a combination of sources. In this context, the linguistic-cultural background also influences the individual's geographical concepts and spatial cognition. At the same time, there are general features, organizing principles in spatial cognition resulting from the mechanisms of cognition, which influence the development of the mental map and name-giving practices as well. A good example is that one can only define a place in relation to another place, and this relation is often reflected in place names. Closely connected to this, is the view of centre-periphery relations in space, which is often manifested in discourse about places and sometimes in the meanings of place names, as well. The connotative meaning attached to words can also be mentioned as a common feature, and this is present both in the organization of discourse about space and in place names. These interrelated principles may apply in different ways to different areas, communities and cultures. 